\title{
Including high-frequency variability in coastal ocean acidification projections
}

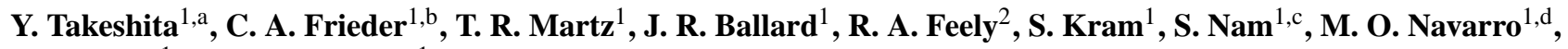 \\ N. N. Price ${ }^{1, \mathrm{e}}$, and J. E. Smith ${ }^{1}$ \\ ${ }^{1}$ Scripps Institution of Oceanography, University of California San Diego, La Jolla, CA 92093, USA \\ ${ }^{2}$ Pacific Marine Environmental Laboratory, NOAA, Seattle, WA 98115, USA \\ anow at: Carnegie Institution for Science, Stanford, CA 94305, USA \\ b now at: University of Southern California, Los Angeles, CA 90089, USA \\ ${ }^{c}$ now at: Research Institution of Oceanography/School of Earth and Environmental Sciences, Seoul National University, \\ Seoul 151-742, South Korea \\ d now at: California State University Monterey Bay, Seaside, CA 93955, USA \\ enow at: Bigelow Laboratory for Ocean Sciences, East Boothbay, ME 04544, USA
}

Correspondence to: Y. Takeshita (ytakeshita@carnegiescience.edu)

Received: 15 April 2015 - Published in Biogeosciences Discuss.: 13 May 2015

Revised: 30 August 2015 - Accepted: 24 September 2015 - Published: 14 October 2015

\begin{abstract}
Assessing the impacts of anthropogenic ocean acidification requires knowledge of present-day and future environmental conditions. Here, we present a simple model for upwelling margins that projects anthropogenic acidification trajectories by combining high-temporal-resolution sensor data, hydrographic surveys for source water characterization, empirical relationships of the $\mathrm{CO}_{2}$ system, and the atmospheric $\mathrm{CO}_{2}$ record. This model characterizes $\mathrm{CO}_{2}$ variability on timescales ranging from hours (e.g., tidal) to months (e.g., seasonal), bridging a critical knowledge gap in ocean acidification research. The amount of anthropogenic carbon in a given water mass is dependent on the age; therefore a density-age relationship was derived for the study region and then combined with the 2013 Intergovernmental Panel on Climate Change $\mathrm{CO}_{2}$ emission scenarios to add density-dependent anthropogenic carbon to the sensor time series. The model was applied to time series from autonomous $\mathrm{pH}$ sensors deployed in the surf zone, kelp forest, submarine canyon edge, and shelf break in the upper $100 \mathrm{~m}$ of the Southern California Bight. All habitats were within $5 \mathrm{~km}$ of one another, and exhibited unique, habitatspecific $\mathrm{CO}_{2}$ variability signatures and acidification trajectories, demonstrating the importance of making projections in the context of habitat-specific $\mathrm{CO}_{2}$ signatures. In general, both the mean and range of $p \mathrm{CO}_{2}$ increase in the future,
\end{abstract}

with the greatest increase in both magnitude and range occurring in the deeper habitats due to reduced buffering capacity. On the other hand, the saturation state of aragonite $\left(\Omega_{\text {Ar }}\right)$ decreased in both magnitude and range. This approach can be applied to the entire California Current System, and upwelling margins in general, where sensor and complementary hydrographic data are available.

\section{Introduction}

It has become increasingly apparent that upwelling systems, including the California Current System (CCS), are particularly vulnerable to anthropogenic ocean acidification due to their unique physical and chemical traits (Feely et al., 2008, 2010; Gruber et al., 2012; Hauri et al., 2013a, b). Upwelled waters have been isolated from the atmosphere and are naturally elevated in $\mathrm{CO}_{2}$ from remineralization of organic matter; depending on the age of the upwelled water mass it may also contain anthropogenic carbon (Harris et al., 2013; Sabine et al., 2002). Recent observations estimate the saturation horizon with respect to aragonite (depth at which $\Omega_{\mathrm{Ar}}=1$ ) along the CCS has shoaled by approximately $50 \mathrm{~m}$ since preindustrial times, and undersaturated waters $\left(\Omega_{\mathrm{Ar}}<\right.$ 1) have been observed at the surface near the California- 
Oregon border during a strong upwelling event (Alin et al., 2012; Feely et al., 2008; Harris et al., 2013). Furthermore, the rate of acidification (i.e., $\Delta \mathrm{pH} \mathrm{yr}^{-1}$ ) is expected to be significantly higher along upwelling margins than observed in the surface open ocean (Bates et al., 2014; Gruber et al., 2012; Hauri et al., 2013b; Leinweber and Gruber, 2013; Rykaczewski and Dunne, 2010) due to the reduced buffering capacity of seawater at higher levels of $\mathrm{CO}_{2}$ (Frankignoulle, 1994). This effect has caused parts of the CCS to venture beyond the envelope (defined as mean $\pm 1 \mathrm{SD}$ ) from modeled preindustrial $\Omega_{\mathrm{Ar}}$ conditions (Hauri et al., 2013b). This is a concern because organisms may need to survive outside of the environmental conditions to which they are acclimatized, and the evolutionary potential for key ecological species to adapt to such rapid and unprecedented changes is poorly understood. For example, a significant decrease in calcareous benthic organisms was observed along a natural $\mathrm{pH}$ gradient near a cold volcanic $\mathrm{CO}_{2}$ vent (Hall-Spencer et al., 2008; Kroeker et al., 2011). However, some calcareous organisms such as limpets seemed to have adapted to higher $\mathrm{CO}_{2}$ levels compared to corals and mussels in the same system (Rodolfo-Metalpa et al., 2011). Furthermore for upwelling margins, $\mathrm{CO}_{2}$ covaries with other environmental stressors such as temperature and $\mathrm{O}_{2}$ (Reum et al., 2015), making predictions more difficult due to potential nonlinear synergistic effects (Frieder et al., 2014).

A critical component in making accurate impact assessments of ocean acidification is the development of robust, ecosystem-specific projections of future $\mathrm{CO}_{2}$ conditions (Andersson et al., 2013; Cai et al., 2011; Feely et al., 2009, 2010; McNeil and Matear, 2008; Sunda and Cai, 2012). Development of surface, open-ocean acidification projections has been relatively straightforward, as they rely on welldefined chemical principles of $\mathrm{CO}_{2}$ equilibrium at the airsea interface (Byrne et al., 2010; Lauvset and Gruber, 2014). Models become more complicated when attempting to resolve biological and physical processes that contribute significantly to the natural variability in the system. For example, biologically mediated "enhanced acidification" was identified in the northern Gulf of Mexico, causing significantly faster rates of acidification than the open ocean (Cai et al., 2011). On many tropical coral reefs, seasonal patterns in $\mathrm{CO}_{2}$ are minimal, whereas the dominant frequency of variability occurs on diel and tidal frequencies (Hofmann et al., 2011). On upwelling margins, both biological and physical processes contribute to the observed natural variability in carbonate conditions (Fassbender et al., 2011).

One approach to develop region-specific ocean acidification projections is to apply an eddy-resolving regional ocean model system (ROMS) coupled with a biogeochemical component, as has been developed for the CCS (Gruber et al., 2011, 2012; Hauri et al., 2013b). Such models have highlighted the importance of capturing physical and biological processes in highly dynamic upwelling systems. The model simulations show complex spatiotemporal variability (Hauri et al., 2013b), and predict that the frequency of "corrosive" upwelling events will intensify in both magnitude and duration by the year 2050 (Hauri et al., 2013a). However, the eddy-resolving ROMS project $p \mathrm{CO}_{2}$ and saturation state conditions on a $5 \mathrm{~km}$ grid, whereas many marine animals experience the environment on the scale of centimeters to meters. In addition, regional models can largely resolve eventscale (weeks) and seasonal features, but cannot capture fluctuations on diel to tidal timescales, which can be the dominant frequency of variability in many near-shore environments (Duarte et al., 2013; Frieder et al., 2012; Hofmann et al., 2011). Due to this discrepancy in both space and time, numerical models tend to underestimate or entirely miss the high-frequency variability that exists for the microclimate of organisms.

To transition from region-specific to habitat-specific ocean acidification projections, high-temporal-resolution data from autonomous chemical sensors deployed across many habitat types can be used to directly quantify the full range of present-day carbonate conditions (Harris et al., 2013; Hofmann et al., 2011, 2014; Martz et al., 2014; Sutton et al., 2014). The CCS supports many ecosystems that are of great ecological and economic value. In particular, there is great habitat and species diversity near-shore on the shelf, which includes a large number of commercially important invertebrates and fishes. Habitats in the region include bays and estuaries, rocky and sandy intertidal, eelgrass beds and kelp forests, sub-tidal reefs, canyons, and extensive sandy sea floor. There are many endangered and harvested benthic organisms that inhabit only one or a subset of these habitats.

Sensor data provide key observations for the mechanistic understanding of the controls on environmental conditions, and are particularly needed for coastal marine environments where complex physical and biological processes influence the observed variability. For example, sensor data from a near-shore kelp forest in the southern CCS revealed that local biological feedbacks and episodic upwelling events were the dominant drivers of $\mathrm{CO}_{2}$ variability, with $p \mathrm{CO}_{2}$ fluctuating by $600 \mu$ atm at $17 \mathrm{~m}$ water depth (Frieder et al., 2012). This scale of variability associated with near-shore environments is not captured by regional model simulations, but is most relevant for organisms living inside the kelp forest.

Here, we present an anthropogenic ocean acidification model to project $\mathrm{CO}_{2}$ chemistry into the future by combining autonomous chemical sensor data, regional empirical relationships for the $\mathrm{CO}_{2}$ system (Alin et al., 2012), hydrographic data, and the atmospheric $\mathrm{CO}_{2}$ record (Keeling et al., 2005). This model was applied to four habitats ranging from the surface to $100 \mathrm{~m}$ water depth and all within $5 \mathrm{~km}$ of each other in the Southern California Bight (SCB). Each site showed distinct $\mathrm{CO}_{2}$ variability signatures and acidification trajectories, highlighting the importance of interpreting ocean acidification projections in the context of present and future habitat-specific $\mathrm{CO}_{2}$ signatures. Implications for future ocean acidification research are discussed. 


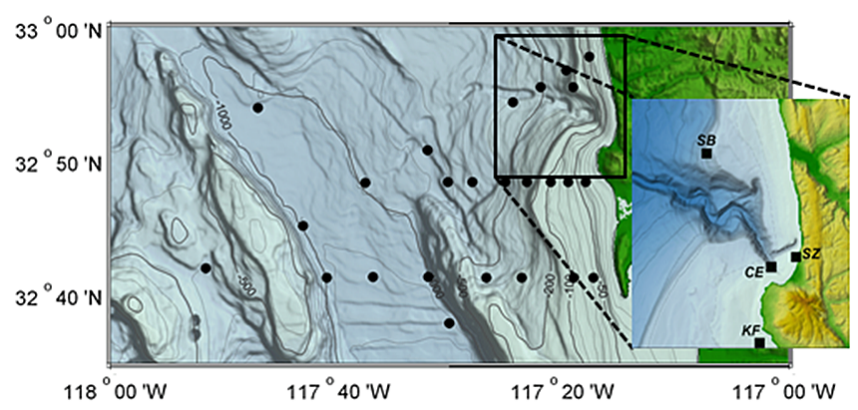

Figure 1. Map of study region. Hydrographic stations (black dots) and sensor deployment sites (black squares) are shown. Initials are as follows: CE, canyon edge; SB, shelf break; SZ, surf zone; and $\mathrm{KF}$, kelp forest.

\section{Methods}

\subsection{Study sites}

Moored autonomous sensor packages SeapHOx or SeaFET (Bresnahan et al., 2014) were deployed at four depths (4, 17,30 , and $88 \mathrm{~m}$ ) within several distinct habitats on the San Diego continental shelf for 1 year starting June 2012 (Fig. 1). All sensors were deployed near the seafloor; the three shallowest sensors were deployed within $3 \mathrm{~m}$ of the bottom, and the deepest sensor was moored $12 \mathrm{~m}$ above the seafloor (Table 1).

A SeaFET was deployed at the Ellen Browning Scripps Pier $2 \mathrm{~m}$ above the benthos as a part of the Scripps Ocean Acidification Real-time Monitoring Program. The sensor was located approximately $400 \mathrm{~m}$ from the shore in the surf zone. Weekly discrete samples for total alkalinity (TA) and dissolved inorganic carbon (DIC) were taken alongside the sensors for calibration and quality control following standard protocols (Dickson et al., 2007). The sensor was serviced every 1-2 months to remove biofouling organisms.

The La Jolla kelp forest is part of the South La Jolla State Marine Reserve and is characterized by a dense population of Macrocystis pyrifera. The chemical variability in this ecosystem is strongly influenced by regional physical processes (e.g., upwelling and stratification) and local biological feedbacks (e.g., production and respiration). A SeapHOx was deployed at $17 \mathrm{~m}$ in the southern portion of the kelp forest, $3 \mathrm{~m}$ above the bottom. The reader is referred to Frieder et al. (2012) for further details on site and deployment description.

The La Jolla canyon is a submarine canyon plunging from approximately $20 \mathrm{~m}$ to a depth of $1000 \mathrm{~m}$ within several kilometers from shore. A SeapHOx was deployed over a sandy bottom at the southern canyon edge at $30 \mathrm{~m}$ depth within the Matlahuayl state marine reserve; the $\mathrm{O}_{2}$ sensor malfunctioned and thus is not included. The water in the La Jolla canyon is characterized by higher salinity and lower temperature, $\mathrm{O}_{2}$, and $\mathrm{pH}$ (data not shown). Tidal energy in submarine canyons is significantly amplified (Swart et al., 2011), bring- ing deep water from the canyon to the canyon edge. Therefore, physical forcings are the dominant drivers for chemical variability at this site (Navarro et al., 2013).

The Del Mar buoy was first deployed in 2006 at $100 \mathrm{~m}$ off of Del Mar in northern San Diego at the shelf break, and has provided continuous time series data (e.g., temperature, salinity, oxygen, and current) at discrete depths (Frieder et al., 2012; Send and Nam, 2012). A SeaFET sensor was deployed on the mooring at $88 \mathrm{~m}$ in 2011, and has provided a near-continuous time series of $\mathrm{pH}$ since. Colocated sensors include temperature, salinity (SBE 37), and dissolved oxygen $\left(\mathrm{O}_{2} ;\right.$ Aanderaa optode). Water at this depth is isolated from the atmosphere and below the euphotic zone, and thus influenced primarily by upwelling and tidal dynamics.

\subsection{Cruise data}

Hydrographic data were collected aboard R/V Melville during the student-led San Diego Coastal Expedition cruises in June/July and December 2012 (Fig. 1). The SCB is characterized by relatively weak (compared to the northern CCS) but nearly year-round upwelling. However, there is a clear seasonal cycle based on climatological data, where upwelling intensifies generally between April and August, with the maximum occurring in May (Bograd et al., 2009). The cruises therefore corresponded with upwelling (June/July) and non-upwelling (December) seasons. Water samples were collected at stations ranging from $>100 \mathrm{~km}$ from shore at $1200 \mathrm{~m}$ water depth, to within $5 \mathrm{~km}$ from shore at $30 \mathrm{~m}$ depth. Discrete samples were analyzed for $\mathrm{O}_{2}, \mathrm{pH}$, and DIC; duplicate samples were collected during every cast.

Discrete samples for $\mathrm{O}_{2}$ were collected and analyzed by titration using a custom-built system (Martz et al., 2012). The titrant was standardized prior to and after each cruise using $\mathrm{KIO}_{3}$ standard solutions prepared in house (Fisher, lot $105595)$; no detectable drift was observed for either cruise. Precision was $\pm 0.6 \mu \mathrm{mol} \mathrm{kg}^{-1}$ (duplicate $n=62,1 \mathrm{SD}$ ), and the accuracy was estimated to be $\pm 0.5 \%$ because $\mathrm{KIO}_{3}$ standards were not recrystallized (Emerson, 1999).

Samples for DIC and $\mathrm{pH}$ were collected in 150 or $250 \mathrm{~mL}$ Pyrex serum bottles ( $13 \mathrm{~mm}$ neck) following standard procedures (Dickson et al., 2007). However, rather than leaving headspace, the bottle was filled completely, and a gray butyl stopper was inserted to prevent gas exchange; samples were analyzed within $4 \mathrm{~h}$ of collection.

DIC samples were analyzed using a custom-built system based on an infrared analyzer (LI-COR 7000) similar to systems built by others (Friederich et al., 2002; O'Sullivan and Millero, 1998). The DIC measurements were calibrated using certified reference materials provided by the Dickson Lab at SIO by applying a gain correction (slope) and assuming an offset of zero (intercept). The reference materials were stored in $\mathrm{CO}_{2}$-impermeable bags ( $3 \mathrm{~L}$ Scholle DuraShield ${ }^{\circledR}$ ) and were measured frequently throughout the cruise. The stability of the reference material in the bag was verified 
Table 1. Summary of sensor deployments

\begin{tabular}{llrrrrr}
\hline Habitat type & Deployment site & $\mathrm{DD}^{\mathrm{a}}$ & $\mathrm{BD}^{\mathrm{b}}$ & Latitude & Longitude & Days $^{\mathrm{c}}$ \\
\hline Surf zone & Scripps pier & 4 & 6 & $32.87^{\circ} \mathrm{N}$ & $117.26^{\circ} \mathrm{W}$ & 122 \\
Kelp forest $_{\text {Canyon edge }}^{\mathrm{d}}$ & La Jolla kelp forest & 17 & 20 & $32.81^{\circ} \mathrm{N}$ & $117.29^{\circ} \mathrm{W}$ & 128 \\
Shelf break & Del Mar buoy & 88 & 100 & $32.94^{\circ} \mathrm{N}$ & $117.32^{\circ} \mathrm{W}$ & 335 \\
\hline
\end{tabular}

${ }^{a}$ Sensor deployment depth in meters. ${ }^{b}$ Bottom depth in meters. ${ }^{\mathrm{c}}$ Total deployment days between June 2012 and June 2013. ${ }^{\mathrm{d}} \mathrm{A}$ linear drift correction for salinity was applied for two of the four deployments.

by daily measurements of a new bottle; no drift was observed. Precision and accuracy of the DIC measurements were $\pm 2.5 \mu \mathrm{mol} \mathrm{kg}^{-1}$ (duplicate $n=67,1 \mathrm{SD}$ ).

Samples for $\mathrm{pH}$ were analyzed spectrophotometrically at $20^{\circ} \mathrm{C}$ (Clayton and Byrne, 1993) using an automated system (Carter et al., 2013). The pH is reported on the total hydrogen ion concentration scale. The indicator dye ( $m$-cresol purple, ACROS lot A0264321) was used as received from the manufacturer without further purification. An offset was applied based on measurements in certified Tris buffer provided by the Dickson Lab. The precision and accuracy of the measurements were estimated to be \pm 0.0015 (duplicate $n=86$, $1 \mathrm{SD}$ ) and \pm 0.02 (Liu et al., 2011), respectively. TA and $p \mathrm{CO}_{2}$ were calculated using CO2SYS (van Heuven et al., 2011), with pH and DIC as inputs and carbonic acid dissociation constants from Mehrbach et al. (1973) refit by Lueker et al. (2000).

\subsection{Sensor data}

The SeapHOx and SeaFET sensor packages utilize a modified Honeywell Durafet III pH combination electrode for high-frequency pH measurements (Martz et al., 2010). These sensor packages have been successfully deployed in ecosystems worldwide (Frieder et al., 2012; Hofmann et al., 2011; Kroeker et al., 2011; Martz et al., 2014; Price et al., 2012), and have been shown to have excellent stability in seawater for months to years (Bresnahan et al., 2014). The SeapHOx is an integrated sensor package that also consists of an Aanderaa 3835 oxygen optode and a Sea-Bird SBE 37 conductivity-temperature sensor all plumbed into a pumped flow stream; the SeaFET measures $\mathrm{pH}$ using a passively flushed cell. Sampling frequencies were $1 \mathrm{~h}^{-1}$ or greater at all depths.

All $\mathrm{pH}$ measurements were calibrated based on discrete TA and DIC samples taken alongside the sensor, at minimum at the beginning and end of each sensor deployment $(n>4$ for every site), as recommended by the best practices (Bresnahan et al., 2014). The resolution of the $\mathrm{pH}$ measurements is better than $0.0005 \mathrm{pH}$, stability is estimated to be better than 0.005 , and accuracy is estimated to be \pm 0.015 . Sensors were removed periodically for maintenance, but all were deployed for $>50$ days during both the upwelling and relaxation season.
At the surf zone (surface waters), a constant TA value of $2240 \mu \mathrm{mol} \mathrm{kg}^{-1}$ was assumed, since discrete TA samples showed low variability (2240 \pm 7 (1 SD) $\mu \mathrm{mol} \mathrm{kg}^{-1}, n=57$ ). For the three subsurface sensors, TA was estimated (TA ${ }^{\text {est }}$ ) using a regional empirical relationship developed for the CCS, with temperature and salinity as inputs (Alin et al., 2012); an offset of $+8 \mu \mathrm{mol} \mathrm{kg}{ }^{-1}$ was applied to $\mathrm{TA}^{\text {est }}$ based on comparisons to discrete samples collected (root mean squared error $(\mathrm{RMSE})=6 \mu \mathrm{mol} \mathrm{kg}-1, n=25)$. This offset was a persistent feature over multiple years (2010-2012), thus most likely reflecting a regional surface TA influence that is not incorporated in the empirical relationship developed for the whole CCS. DIC, $p \mathrm{CO}_{2}$, and $\Omega_{\mathrm{Ar}}$ were calculated using CO2SYS (van Heuven et al., 2011) with pH sensor data and $\mathrm{TA}^{\mathrm{est}}$ as inputs. Uncertainty for the calculated DIC, $p \mathrm{CO}_{2}$, and $\Omega_{\mathrm{Ar}}$ is $\mathrm{pH}$-dependent but is on average estimated to be $\pm 13 \mu \mathrm{mol} \mathrm{kg}{ }^{-1}, \pm 25 \mu \mathrm{atm}$, and \pm 0.04 , respectively. The daily range of sensor data was calculated by first high-pass-filtering the data with a $36 \mathrm{~h}$ window and then taking the difference between the daily maximum and minimum. The mean daily range was then calculated by averaging the resultant time series.

\subsection{Modeling future carbonate chemistry}

\subsubsection{Approach}

The carbonate conditions were modeled by decreasing or increasing DIC while using TA conditions from 2012. Modeled projections were made for preindustrial times and for year $t$, where $t$ ranges between 2012 and 2100. The model presented here is based on the $\Delta C_{t}^{*}$ approach (Gruber et al., 1996), but instead of using tracers to estimate the age of the water mass (e.g., $\mathrm{CFCs}$ ), we used the atmospheric $\mathrm{CO}_{2}$ record as a quasiage tracer. The age of the water mass ranged between 0 and 50 years in this study region. Although this approach must be used with caution, we demonstrate that our estimates are in good agreement with previously published anthropogenic carbon inventory estimates using age tracer measurements in this region (Feely et al., 2008; Sabine et al., 2002). In this model, it was assumed that ocean acidification is due to anthropogenic $\mathrm{CO}_{2}$ invasion through the air-sea interface alone. We also assumed that both the path of a particular water mass between the subduction and upwelling site and the 
rate of remineralization processes remain unchanged. Sensitivity to these assumptions is explored in the Discussion.

The DIC of the modeled year $t\left(\mathrm{DIC}_{t}\right)$ is calculated by

$\mathrm{DIC}_{\mathrm{t}}=\mathrm{DIC}_{2012}+\Delta \mathrm{DIC}_{\mathrm{anth}}$,

where $\mathrm{DIC}_{2012}$ is the DIC observed in 2012 , and $\Delta \mathrm{DIC}_{\mathrm{anth}}$ is the additional anthropogenic $\mathrm{CO}_{2}$ that the water mass would have absorbed since 2012. Different formulations for $\Delta \mathrm{DIC}_{\mathrm{anth}}$ were used for surface waters (i.e., above the seasonal mixed layer depth, defined here as $\sigma_{\theta} \leq 25.2 \mathrm{~kg} \mathrm{~m}^{-3}$ ) and subsurface waters $\left(\sigma_{\theta}>25.2 \mathrm{~kg} \mathrm{~m}^{-3}\right)$, and are outlined below.

For surface waters, $\Delta \mathrm{DIC}_{\mathrm{anth}}$ was calculated as the difference in surface DIC between year $t$ and 2012. Surface DIC was calculated by assuming atmospheric equilibrium with TA $=2240 \mu \mathrm{mol} \mathrm{kg}^{-1}$ (based on water samples from the Scripps pier) and using $p \mathrm{CO}_{2 \text {,atm }}$ projection under the 2013 IPCC RCP6.0 scenario (Hijioka et al., 2008). Although large deviations from equilibrium conditions are often observed in the coastal ocean due to upwelling and biological production (Hales et al., 2005), the mean $p \mathrm{CO}_{2}$ calculated from sensor data at the surf zone was $394 \pm 43$ (1 SD) $\mu$ atm (Table 2), suggesting that the surface water at the study site was near atmospheric equilibrium.

For subsurface waters, $\Delta \mathrm{DIC}_{\text {anth }}$ was quantified as the increase in DIC due to anthropogenic $\mathrm{CO}_{2}$ when the water parcel was last in contact with the atmosphere. The mass balance of DIC for subsurface waters is

$\mathrm{DIC}=\mathrm{DIC}^{\circ}+\Delta D I C_{\mathrm{bio}}$

where $\mathrm{DIC}^{\circ}$ is the preformed DIC, and $\triangle \mathrm{DIC}_{\text {bio }}$ is the DIC added by remineralization processes in the ocean interior. $\mathrm{DIC}^{\circ}$ can be expressed as the sum of DIC if it were in equilibrium with the atmosphere $\left(\mathrm{DIC}_{\mathrm{eq}}\right)$ and the degree of air-sea disequilibrium due to slow gas exchange kinetics and biological processes $\left(\Delta \mathrm{DIC}_{\text {diseq }}\right)$ :

$\mathrm{DIC}^{\circ}=\mathrm{DIC}_{\mathrm{eq}}+\Delta \mathrm{DIC}_{\text {diseq }}$.

Since anthropogenic $\mathrm{CO}_{2}$ only enters the ocean at the surface, the increase in $\mathrm{DIC}_{\mathrm{eq}}$ represents the anthropogenic ocean acidification signal, $\Delta \mathrm{DIC}_{\mathrm{anth}}$, assuming $\Delta \mathrm{DIC}_{\text {diseq }}$ is invariant with time. However, in order to use this approach, the age of the water parcel must first be quantified, as this determines the $p \mathrm{CO}_{2, \text { atm }}$ with which it was last in contact.

The age of the water parcel was established by combining Eqs. (2) and (3):

$\mathrm{DIC}_{\mathrm{eq}}^{2012-\mathrm{age}}=\mathrm{DIC}-\Delta \mathrm{DIC}_{\mathrm{bio}}-\Delta \mathrm{DIC}_{\mathrm{diseq}}$,

where the superscript denotes the year at which the water parcel was last at the surface (i.e., equal to 2012 minus age of the water mass). The age of the water mass was calculated by comparing the atmospheric $\mathrm{CO}_{2}$ record to the $p \mathrm{CO}_{2, \text { atm }}$

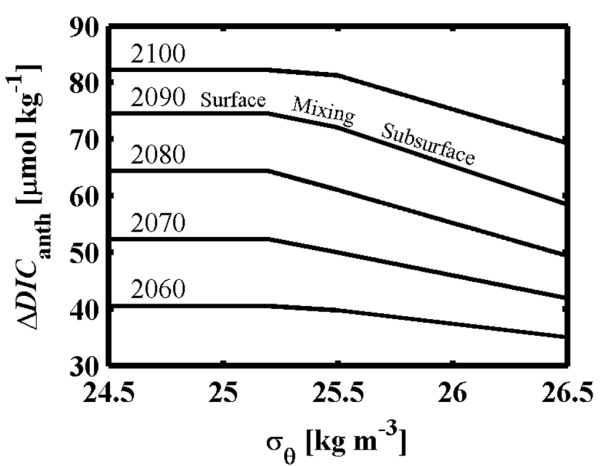

Figure 2. $\triangle \mathrm{DIC}_{\text {anth }}$ as a function of $\sigma_{\theta}$ for certain modeled years (indicated above line) using the IPCC RCP6.0 projection. The three regimes used in this model - surface, mixing, and subsurface - are labeled.

that is necessary to generate $\mathrm{DIC}_{\mathrm{eq}}^{2012-\mathrm{age}} . \Delta \mathrm{DIC}_{\mathrm{diseq}}$ was estimated from published values in the region (Sect. 2.4.3). Using this information, we calculated $\Delta \mathrm{DIC}_{\mathrm{anth}}$ by

$\Delta \mathrm{DIC}_{\mathrm{anth}}=\mathrm{DIC}_{\mathrm{eq}}^{t-\text { age }}-\mathrm{DIC}_{\mathrm{eq}}^{2012-\mathrm{age}}$,

where the superscripts denote the year at which the water parcel was last at the surface, and age is the age of the water parcel. For example, if age $=30 \mathrm{yr}$ and $t=2050$, then $\mathrm{CO}_{2}$ projections for the year 2020 would be used to calculate $\mathrm{DIC}_{\mathrm{eq}}^{t-\text { age }}$; $\mathrm{DIC}_{\mathrm{eq}}^{2012-\text { age }}$ was calculated from Eq. (4). The $\triangle \mathrm{DIC}_{\mathrm{anth}}$ for subsurface waters was modeled for each projection year as a linear function of $\sigma_{\theta}$, and the surface and subsurface $\Delta \mathrm{DIC}_{\text {anth }}$ were connected assuming a two-endmember linear mixing between $\sigma_{\theta} 25.2$ and $25.5 \mathrm{~kg} \mathrm{~m}^{-3}$ to prevent step changes (Fig. 2).

\subsubsection{Calculation of $\Delta \mathrm{DIC}_{\text {bio }}$}

$\triangle \mathrm{DIC}_{\text {bio }}$ was quantified following formulations in Sabine et al. (2002):

$\Delta \mathrm{DIC}_{\text {bio }}=r_{\mathrm{C}: \mathrm{O}}(\mathrm{AOU})-0.5\left(\mathrm{TA}_{\mathrm{obs}}-\mathrm{TA}^{\circ}+r_{\mathrm{N}: \mathrm{O}}(\mathrm{AOU})\right)$,

where AOU (apparent oxygen utilization $)=\left(\mathrm{O}_{2, \text { sat }}-\mathrm{O}_{2, \mathrm{obs}}\right)$, $\mathrm{TA}^{\circ}$ is the preformed alkalinity, and the $r$ 's are the elemental remineralization ratios (Anderson and Sarmiento, 1994). The oxygen saturation concentration $\left(\mathrm{O}_{2 \text {,sat }}\right)$ was calculated using the equations in Garcia and Gordon (1992), and TA ${ }^{\circ}$ was estimated based on historical near-surface TA data in the Pacific (Eq. 3 in Sabine et al., 2002). Phosphate concentrations necessary to estimate $\mathrm{TA}^{\circ}$ were not directly measured but instead estimated from a regional empirical relationship using historical data (Supplement); the uncertainty in estimating phosphate using this approach propagates to an error in $\mathrm{TA}^{\circ}$ of $4 \mu \mathrm{mol} \mathrm{kg}-1$. 
Table 2. Mean \pm SD of modeled carbonate parameters at in situ conditions for preindustrial, 2012, 2060, and 2100 using the RCP6.0 projection at each habitat.

\begin{tabular}{lllll}
\hline & Year & $\begin{array}{l}p \mathrm{CO}_{2} \\
(\mu \mathrm{atm})\end{array}$ & $\Omega_{\mathrm{Ar}}$ & $\mathrm{pH}$ \\
\hline Surf zone & Preind. & $267 \pm 26$ & $3.09 \pm 0.21$ & $8.19 \pm 0.034$ \\
$(4 \mathrm{~m})$ & 2012 & $394 \pm 43$ & $2.38 \pm 0.25$ & $8.05 \pm 0.038$ \\
& 2060 & $473 \pm 56$ & $2.09 \pm 0.19$ & $7.98 \pm 0.041$ \\
& 2100 & $619 \pm 80$ & $1.71 \pm 0.18$ & $7.88 \pm 0.045$ \\
\hline Kelp forest & Preind. & $365 \pm 74$ & $2.28 \pm 0.42$ & $8.08 \pm 0.078$ \\
$(17 \mathrm{~m})$ & 2012 & $516 \pm 108$ & $1.77 \pm 0.36$ & $7.95 \pm 0.083$ \\
& 2060 & $683 \pm 156$ & $1.43 \pm 0.33$ & $7.84 \pm 0.094$ \\
& 2100 & $937 \pm 231$ & $1.11 \pm 0.29$ & $7.72 \pm 0.105$ \\
\hline Canyon edge & Preind. & $365 \pm 68$ & $2.29 \pm 0.37$ & $8.08 \pm 0.068$ \\
$(30 \mathrm{~m})$ & 2012 & $529 \pm 105$ & $1.75 \pm 0.31$ & $7.94 \pm 0.075$ \\
& 2060 & $702 \pm 155$ & $1.40 \pm 0.29$ & $7.83 \pm 0.085$ \\
& 2100 & $964 \pm 231$ & $1.09 \pm 0.25$ & $7.70 \pm 0.095$ \\
\hline Shelf break & Preind. & $637 \pm 132$ & $1.38 \pm 0.27$ & $7.86 \pm 0.083$ \\
$(88 \mathrm{~m})$ & 2012 & $878 \pm 149$ & $1.05 \pm 0.18$ & $7.73 \pm 0.070$ \\
& 2060 & $1195 \pm 200$ & $0.80 \pm 0.15$ & $7.61 \pm 0.070$ \\
& 2100 & $1639 \pm 246$ & $0.60 \pm 0.10$ & $7.47 \pm 0.065$ \\
\hline
\end{tabular}

\subsubsection{Estimation of $\Delta \mathrm{DIC}_{\text {diseq }}$}

Making accurate estimates of $\Delta \mathrm{DIC}_{\text {diseq }}$ is important because it is a source of large uncertainty for anthropogenic carbon inventory calculations (Matsumoto and Gruber, 2005). Traditionally, age of the water mass is quantified using tracers such as CFCs and then the $\triangle \mathrm{DIC}_{\text {diseq }}$ is subsequently calculated (Gruber et al., 1996; Sabine and Tanhua, 2010). However, such tracer measurements were not made for this study. Alternatively, we estimated $\Delta \mathrm{DIC}_{\text {diseq }}$ based on $\theta$ and $S$ data to overcome this limitation (Sabine et al., 2002). The mean $\theta$ and $S$ between $\sigma_{\theta}$ of 25.5 and $26.5 \mathrm{~kg} \mathrm{~m}^{-3}$ were $10.0^{\circ} \mathrm{C}$ and 33.9 , respectively, resembling water type 1e in Sabine et al. (2010) with a corresponding $\Delta \mathrm{DIC}_{\text {diseq }}=-6.24 \mu \mathrm{mol} \mathrm{kg}^{-1}$, the value used in this study.

\subsubsection{Calculation of the age of water parcel}

In order to estimate the age of the water mass, we use Eq. (4) to calculate $D I C_{\mathrm{eq}}^{2012-\text { age }}$, which is the DIC of the water parcel that was in equilibrium with the atmosphere when it was last at the surface (i.e., equal to 2012 - age of the water mass). Therefore the age of the water mass can be calculated by comparing the atmospheric $\mathrm{CO}_{2}$ record to the $p \mathrm{CO}_{2, \text { atm }}$ that is necessary to generate $\mathrm{DIC}_{\mathrm{eq}}^{2012-\mathrm{age}}$. The latter was calculated from the fugacity of $\mathrm{CO}_{2}$ of the water mass when it was last in contact with the atmosphere at the time of subduction $\left(f \mathrm{CO}_{2, \mathrm{eq}}^{2012-\text { age }}\right)$, assuming $100 \%$ relative humidity and a barometric pressure of $1 \mathrm{~atm}$ (Dickson, 2007). The year that the water parcel subducted was determined by matching the calculated $\mathrm{CO}_{2, \text { atm }}$ to the mean annual $\mathrm{CO}_{2, \mathrm{~atm}}$
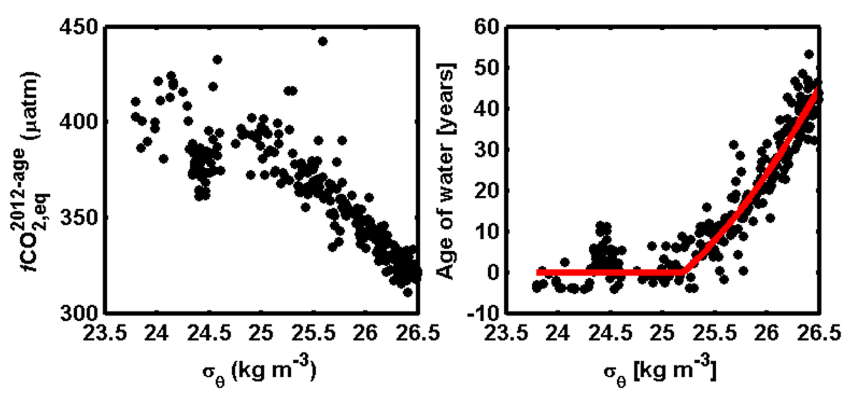

Figure 3. $f \mathrm{CO}_{2 \text {,eq }}^{2012-a g e}$ calculated from hydrographic data (left) and the calculated age $-\sigma_{\theta}$ relationship (right) is shown. Good agreement $\left(R^{2}=0.87\right)$ between the data (black circles) and the fit (age $=8.852\left(\sigma_{\theta}-25.2\right) 2+23.132\left(\sigma_{\theta}-25.2\right)$; red line) is observed (right). Age of surface waters $\left(\sigma_{\theta}<25.2 \mathrm{~kg} \mathrm{~m}^{-3}\right)$ was assumed to be 0 .

record (Keeling et al., 2005); the age is the difference between 2012 and the calculated year (Fig. 3). A relationship between $\sigma_{\theta}$ and the age was established by fitting a secondorder polynomial to the subsurface data $\left(n=186, R^{2}=0.92\right)$ and assuming the age of the surface water $\left(\sigma_{\theta}<25.2\right)$ to be 0 (Fig. 3). The nonzero age of the water that appears around $\sigma_{\theta}=24.4 \mathrm{~kg} \mathrm{~m}^{-3}$ corresponds to the shallow oxygen maximum layer that formed during the summer. However, since this density range is still shallower than the seasonal mixed layer, its age was considered to be 0 . The age of the water ranged between 0 and 50 years between $\sigma_{\theta}$ of 25.2 and $26.5 \mathrm{~kg} \mathrm{~m}^{-3}$. 


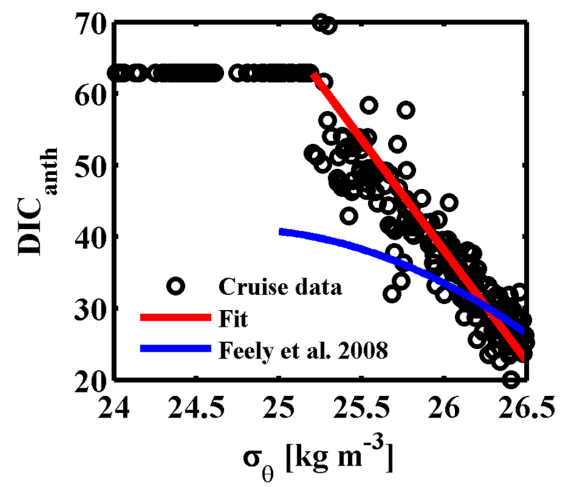

Figure 4. DIC $\mathrm{anth}_{\mathrm{a}}$ as a function of $\sigma_{\theta}$. The calculated values and the fit are represented by black circles and a red line, respectively. The blue line shows DIC $_{\text {anth }}$ using the formulations from Feely et al. (2008).

\subsubsection{Estimation of preindustrial DIC}

In order to calculate the preindustrial DIC, Eq. (3) is written as

$\mathrm{DIC}^{\circ}=\mathrm{DIC}_{\mathrm{eq}}^{\mathrm{prein}}+\mathrm{DIC}_{\mathrm{anth}}+\Delta \mathrm{DIC}_{\mathrm{diseq}}$,

where $\mathrm{DIC}_{\mathrm{anth}}$ represents the anthropogenic carbon present in the water parcel in 2012 , and $\mathrm{DIC}_{\mathrm{eq}}^{\mathrm{prein}}$ is the DIC of the water parcel if it were in equilibrium with $p \mathrm{CO}_{2, \mathrm{~atm}}=280 \mu \mathrm{atm}$. Combining Eqs. (2) and (7) and rearranging gives

$\mathrm{DIC}_{\mathrm{anth}}=\mathrm{DIC}-\Delta \mathrm{DIC}_{\mathrm{bio}}-\mathrm{DIC}_{\mathrm{eq}}^{\text {prein }}+\Delta \mathrm{DIC}_{\mathrm{diseq}}$.

Calculated DIC $\mathrm{anth}_{\text {an }}$ as a function of $\sigma_{\theta}$ is shown in Fig. 4. Note that the values calculated here are in good agreement with published values using age tracers (Feely et al., 2008; Sabine et al., 2002) for higher $\sigma_{\theta}$ but are significantly higher at lower densities. This is because the literature values were quantified using offshore subsurface waters, whereas our study region is near the coast along an upwelling margin, where subsurface waters are brought near the surface and are thus affected by surface processes. The agreement at higher density where surface influence is minimal demonstrates that the model presented here is capable of making accurate estimates of anthropogenic $\mathrm{CO}_{2}$. Furthermore, the comparison illustrates the importance of incorporating surface influence when making acidification projections in shallow, coastal ecosystems. Preindustrial DIC ( $\left.\mathrm{DIC}_{\text {prein }}\right)$ was calculated by subtracting $\mathrm{DIC}_{\text {anth }}$ from DIC observed in 2012. Preindustrial $p \mathrm{CO}_{2}, \Omega_{\mathrm{Ar}}$, and $\mathrm{pH}$ were calculated using $\mathrm{DIC}_{\text {prein }}$ and TA conditions from 2012.

\section{Results}

\subsection{Carbonate chemistry variability observed in 2012}

The results are presented using $\mathrm{pH}, p \mathrm{CO}_{2}$, or $\Omega_{\mathrm{Ar}}$, since $\mathrm{pH}$ was directly measured and $p \mathrm{CO}_{2}$ and $\Omega_{\mathrm{Ar}}$ are commonly used as stress indicators for respiration (Brewer and Peltzer, 2009) and calcification (Langdon et al., 2010), respectively. Across all four sites in 2012, $p \mathrm{CO}_{2}$ increased with depth. In 2012 , the mean $p \mathrm{CO}_{2}$ in the surf zone was near atmospheric equilibrium (394 $\mu \mathrm{atm})$, while the mean $p \mathrm{CO}_{2}$ at $88 \mathrm{~m}$ was $878 \mu \mathrm{atm}$ (Table 2) and reached a maximum of $1270 \mu \mathrm{atm}$. The variability in $p \mathrm{CO}_{2}$ also increased with depth (indicated by the SD of the time series), which was only $43 \mu \mathrm{atm}$ in the surf zone but was $149 \mu$ atm at $88 \mathrm{~m}$ depth. The mean $( \pm 1 \mathrm{SD})$ $\Omega_{\mathrm{Ar}}$ decreased with depth; the mean $\Omega_{\mathrm{Ar}}$ in the surf zone was $2.4 \pm 0.25$, whereas it was $1.05 \pm 0.18$ at $88 \mathrm{~m}$. Undersaturated conditions $\left(\Omega_{\mathrm{Ar}}<1\right)$ were observed $48 \%$ of the time at $88 \mathrm{~m}$ in 2012 but were not observed at other sites. However, unlike $p \mathrm{CO}_{2}$, the variability in $\Omega_{\mathrm{Ar}}$, indicated by the $\mathrm{SD}$, decreased with depth $(0.25$ at the surface to 0.18 at $88 \mathrm{~m})$ (Table 2; see Discussion). The mean $\mathrm{pH}$ decreased with depth; the mean $\mathrm{pH}$ in the surf zone was 8.05 , whereas it was 7.73 at $88 \mathrm{~m}$. The variability in $\mathrm{pH}$ increased with depth until $30 \mathrm{~m}$, but decreased at $88 \mathrm{~m}$ (Table 2).

Distinct, habitat-specific $\mathrm{CO}_{2}$ signatures were observed at the four deployment sites (Figs. 5, 6 and 7). Here, we define habitat-specific $\mathrm{CO}_{2}$ signatures as how $\mathrm{CO}_{2}$ conditions varied in that habitat, regardless of biological or physical origin. In the surf zone, the conditions were near atmospheric equilibrium, with intrusions of higher $p \mathrm{CO}_{2}$ waters through internal tidal bores, a common feature observed in shallow, upwelling environments (Booth et al., 2012; Pineda, 1991); temperature and $\mathrm{pH}$ were correlated during these events (Supplement Fig. S2). This leads to a high, mean daily range of $\mathrm{CO}_{2}$ conditions (e.g., $96 \mu \mathrm{atm}, 0.46$, and 0.085 for $p \mathrm{CO}_{2}$, $\Omega_{\mathrm{Ar}}$, and $\mathrm{pH}$, respectively) (Table 3 ). However, the signature from the internal bores usually only lasted several hours, and remained at near atmospheric equilibrium for the majority of the time. Higher occurrence of tidal bores was observed during the spring and summer months relative to winter (Fig. 5), consistent with previous observations (Pineda, 1991). The mean diel range of $p \mathrm{CO}_{2}$ at the surf zone was significantly higher than measurements made by a surface mooring located offshore in the SCB (Leinweber et al., 2009).

The mean $( \pm \mathrm{SD}) \mathrm{CO}_{2}$ conditions in the kelp forest and the canyon edge were similar, and the SDs for $\Omega_{\mathrm{Ar}}$ and $\mathrm{pH}$ were the highest among the sites (Table 2). However, the timescales of the variability were different, indicating that distinct processes control the $\mathrm{CO}_{2}$ conditions in these two habitats. For example, the mean daily range for all the variables was significantly higher at the canyon edge compared to the kelp forest (Table 3). Submarine canyons are known to amplify tidal energy (Navarro et al., 2013; Swart et al., 2011), and, in fact, periodic variability at the canyon edge 


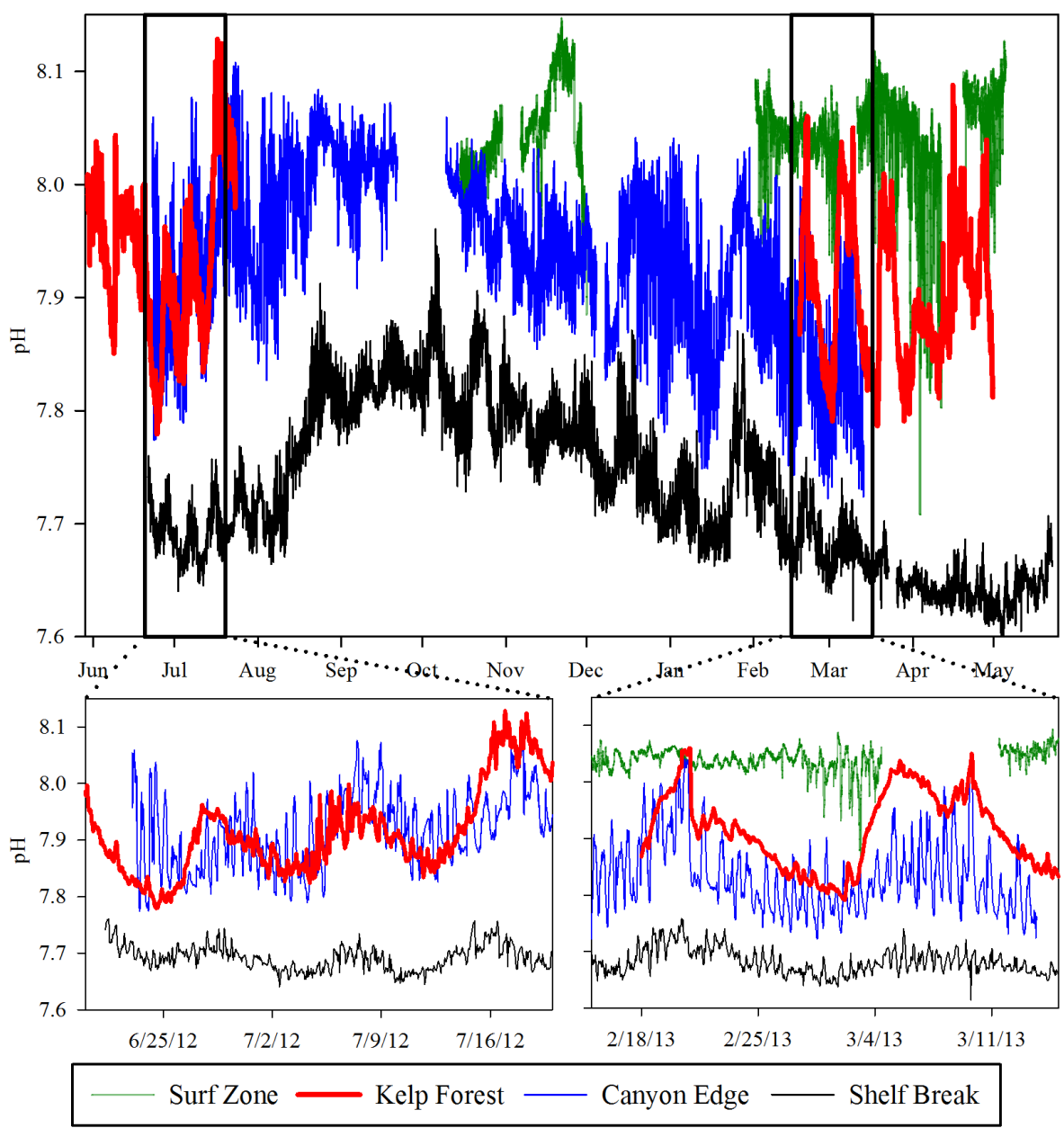

Figure 5. Time series of sensor pH between June 2012 and June. The two lower panels are month-long snapshots. pH is reported at in situ conditions.

Table 3. Mean daily range of carbonate parameters at in situ conditions for 2012 at each habitat.

\begin{tabular}{lrrc}
\hline & $\begin{array}{r}p \mathrm{CO}_{2} \\
(\mu \mathrm{atm})\end{array}$ & $\Omega_{\mathrm{Ar}}$ & $\mathrm{pH}$ \\
\hline Surf zone & 96 & 0.46 & 0.085 \\
Kelp forest & 68 & 0.22 & 0.054 \\
Canyon edge & 167 & 0.48 & 0.120 \\
Shelf break & 110 & 0.14 & 0.053 \\
\hline
\end{tabular}

occurred on semi-diurnal and diurnal cycles, indicative of tidal forcing. Temperature and $\mathrm{pH}$ were correlated on these shorter timescales (Fig. S2), further supporting the fact that the variability was dominantly driven by intrusion of cold, deep waters from the canyon.

While tidal forcings and daily biological production are drivers for carbonate chemistry in the La Jolla kelp forest, the largest variability occurred on event timescales (Frieder et al., 2012); event timescales are defined as longer than a day but shorter than several weeks. For example, $\mathrm{pH}, p \mathrm{CO}_{2}$, and $\Omega_{\mathrm{Ar}}$ regularly changed by up to $0.3,250 \mu \mathrm{atm}$, and 1.3 on event timescales, more than 3 times the mean daily range. Variability on event timescales is due to a combination of changing water mass, stratification, and biological respiration (Frieder et al., 2012). In addition, a clear seasonal pattern was observed at the canyon edge, where higher $p \mathrm{CO}_{2}$ and lower $\mathrm{pH}$ and $\Omega_{\mathrm{Ar}}$ were observed during the spring and summer months (upwelling season) and lower $p \mathrm{CO}_{2}$ and higher $\mathrm{pH}$ and $\Omega_{\mathrm{Ar}}$ were observed during the fall and winter (relaxation season). Due to incomplete data coverage, a seasonal trend at the kelp forest and pier sites could not be discerned. The largest seasonal change among the four sites for $\Omega_{\mathrm{Ar}}$ $(\sim 1)$ was observed at the canyon edge; $p \mathrm{CO}_{2}$ differed by roughly 200-300 $\mu$ atm between the two seasons.

The shelf break experienced the highest mean $\mathrm{CO}_{2}$ conditions and the highest and lowest SD for $p \mathrm{CO}_{2}(149 \mu \mathrm{atm})$ and $\Omega_{\mathrm{Ar}}(0.18)$, respectively (Table 2$)$; the SD of $\mathrm{pH}(0.070)$ was lower than the kelp forest $(0.083)$ or the canyon edge (0.075). Variability on tidal, event, and seasonal timescales 

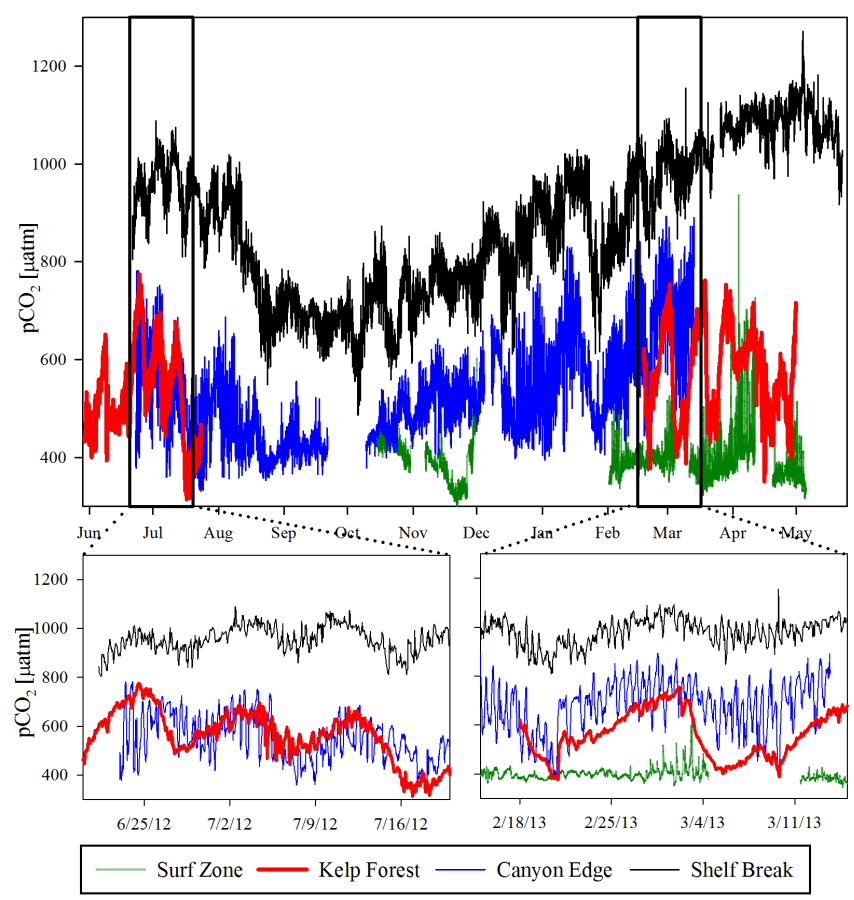

Figure 6. Time series of $p \mathrm{CO}_{2}$ calculated from sensor $\mathrm{pH}$ and $\mathrm{TA}^{\mathrm{est}}$ between June 2012 and June 2013. The two lower panels are monthlong snapshots. $p \mathrm{CO}_{2}$ is reported at in situ conditions.

were observed at this site (Figs. 5, 6, and 7), as has been previously reported for oxygen (Send and Nam, 2012). In general, upwelling on event timescales led to greater changes in $p \mathrm{CO}_{2}$ and $\mathrm{pH}$ than on tidal frequencies (Figs. 5 and 6). The largest variability for all parameters occurred between the seasons, where changes in $p \mathrm{CO}_{2}, \mathrm{pH}$, and $\Omega_{\mathrm{Ar}}$ were approximately $350 \mu \mathrm{atm}, 0.2$, and 0.5 , respectively. The close proximity of these four sites demonstrates the wide variety of habitat-specific $\mathrm{CO}_{2}$ signatures that exist over a small spatial scale, especially in near-shore environments.

\subsection{Modeled carbonate chemistry}

Each habitat showed distinct trends in both modeled mean and variability in $p \mathrm{CO}_{2}, \mathrm{pH}$, and $\Omega_{\mathrm{Ar}}$ owing to increased levels of anthropogenic DIC ( $\Delta$ DIC $\left._{\text {anth }}\right)$ (Table 2$)$. For example, the mean $p \mathrm{CO}_{2}$ at the surf zone $(4 \mathrm{~m})$, canyon edge $(30 \mathrm{~m})$, and shelf break ( $88 \mathrm{~m}$ ) increased by 225,435 , and $738 \mu \mathrm{atm}$, respectively, from 2012 to 2100; this drastic difference in increased mean $p \mathrm{CO}_{2}$ is driven by different buffer factors due to depth differences among the sites. The increase in variability (i.e., SD) was also larger at $88 \mathrm{~m}(97 \mu \mathrm{atm})$ compared to the surf zone $(37 \mu \mathrm{atm})$, although the largest increase occurred at the canyon edge at $30 \mathrm{~m}(126 \mu \mathrm{atm})$ (Table 2). Similar trends were observed for mean $\mathrm{pH}$, where the largest mean decrease in $\mathrm{pH}$ occurred at $88 \mathrm{~m}$ water depth (0.26). However, the SD increased into the future for the three shallowest sites, whereas the SD decreased at the shelf break

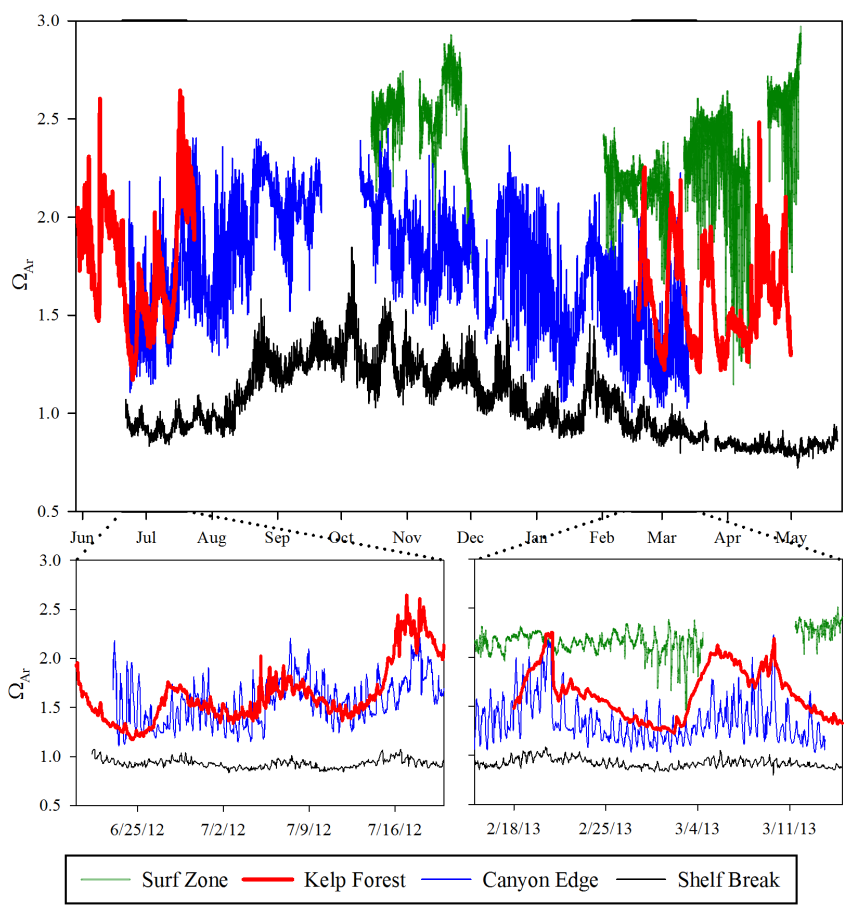

Figure 7. Time series of $\Omega_{\mathrm{Ar}}$ calculated from sensor $\mathrm{pH}$ and $\mathrm{TA}^{\mathrm{est}}$ between June 2012 and June 2013. The two lower panels are monthlong snapshots. $\Omega_{\mathrm{Ar}}$ is reported at in situ conditions.

( $88 \mathrm{~m})$. In contrast, the largest decrease in the mean $\Omega_{\mathrm{Ar}}$ occurred at the surface relative to the deeper sites, whereas the decrease in range was equivalent across all depths.

The measured and modeled time series for $p \mathrm{CO}_{2}$ and $\Omega_{\mathrm{Ar}}$ at the shelf break for the year 2012 and 2100 are shown in Figs. 8 and 9. The variability in $p \mathrm{CO}_{2}$ increases on both seasonal and tidal timescales; the seasonal amplitude increases from approximately 350 to $650 \mu \mathrm{atm}$ and the mean daily range increases from 110 to $325 \mu \mathrm{atm}$ by 2100 . This greater variability is in addition to an increase in mean $p \mathrm{CO}_{2}$ of $>700 \mu \mathrm{atm}$. On the other hand, the variability in $\Omega_{\mathrm{Ar}}$ on both seasonal and shorter timescales decreases. Furthermore, the shelf break is projected to experience undersaturated waters over $90 \%$ of the time by 2060, compared to $48 \%$ in 2012 . Similar patterns were observed in the kelp forest as well, where both the mean conditions and variability in $p \mathrm{CO}_{2}$ increased and $\Omega_{\mathrm{Ar}}$ decreased (Fig. 10). The largest variability at the kelp forest occurred on timescales of days to weeks, and high-frequency ( $<1$ day) variability was significantly smaller than at the shelf break. Therefore benthic organisms at the kelp forest would experience elevated $\mathrm{CO}_{2}$ conditions for prolonged periods of time, with only intermittent exposure to near-atmospheric conditions.

Preindustrial $p \mathrm{CO}_{2}$ and $\Omega_{\mathrm{Ar}}$ were compared to conditions observed in 2012 (Table 2). At most sites, the observed $p \mathrm{CO}_{2}, \mathrm{pH}$, and $\Omega_{\mathrm{Ar}}$ in 2012 were already outside of their preindustrial variability envelopes (defined as mean $\pm 1 \mathrm{SD}$ ), 


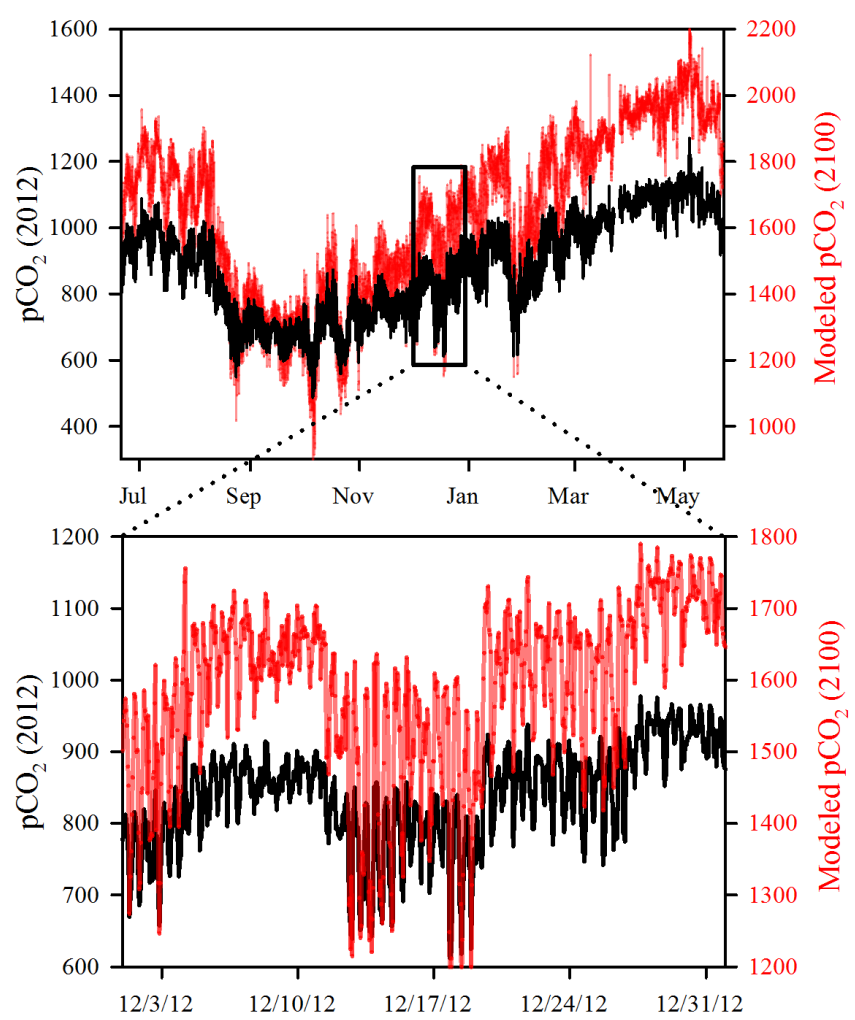

Figure 8. Observed $p \mathrm{CO}_{2}$ in 2012 (black) and modeled $p \mathrm{CO}_{2}$ using the IPCC RCP 6.0 scenario for the year 2100 (red) at the Del Mar buoy ( $88 \mathrm{~m}$ ) over an annual cycle (top). A close-up for the month of December is shown in the bottom panel. Note that the range, but not the absolute values, of the vertical axes for each figure is the same.

which is consistent with results from a previous ROMS simulation in the CCS (Hauri et al., 2013b). These results suggest that all habitats studied here have left, or are about to leave, the $p \mathrm{CO}_{2}, \mathrm{pH}$, and $\Omega_{\mathrm{Ar}}$ conditions that were experienced during preindustrial times. This is significant as organisms at these sites are now surviving in conditions that are significantly different than the conditions under which their ancestors evolved.

The modeled habitat-specific $p \mathrm{CO}_{2}$ and $\Omega_{\mathrm{Ar}}$ conditions for preindustrial, 2012, 2060, and 2100 are shown in Fig. 11. The histograms represent the full range of carbonate conditions at each habitat that was captured by the sensors, which includes both the seasonal and high-frequency variability. The shape of each distribution skews towards more "corrosive" conditions at all sites as the model steps forward into the future. This translates to not only increases in mean $p \mathrm{CO}_{2}$ but also greater extremes and amount of time spent in extremes.

The projected $p \mathrm{CO}_{2}$ and $\Omega_{\mathrm{Ar}}$ envelopes (mean $\pm \mathrm{SD}$ ) at each habitat throughout the modeled period are shown in Fig. 12. An increasing rate of change in $p \mathrm{CO}_{2}\left(\Delta p \mathrm{CO}_{2} \mathrm{yr}^{-1}\right)$ is observed, whereas $\Omega_{\mathrm{Ar}}$ tends to decrease at a relatively

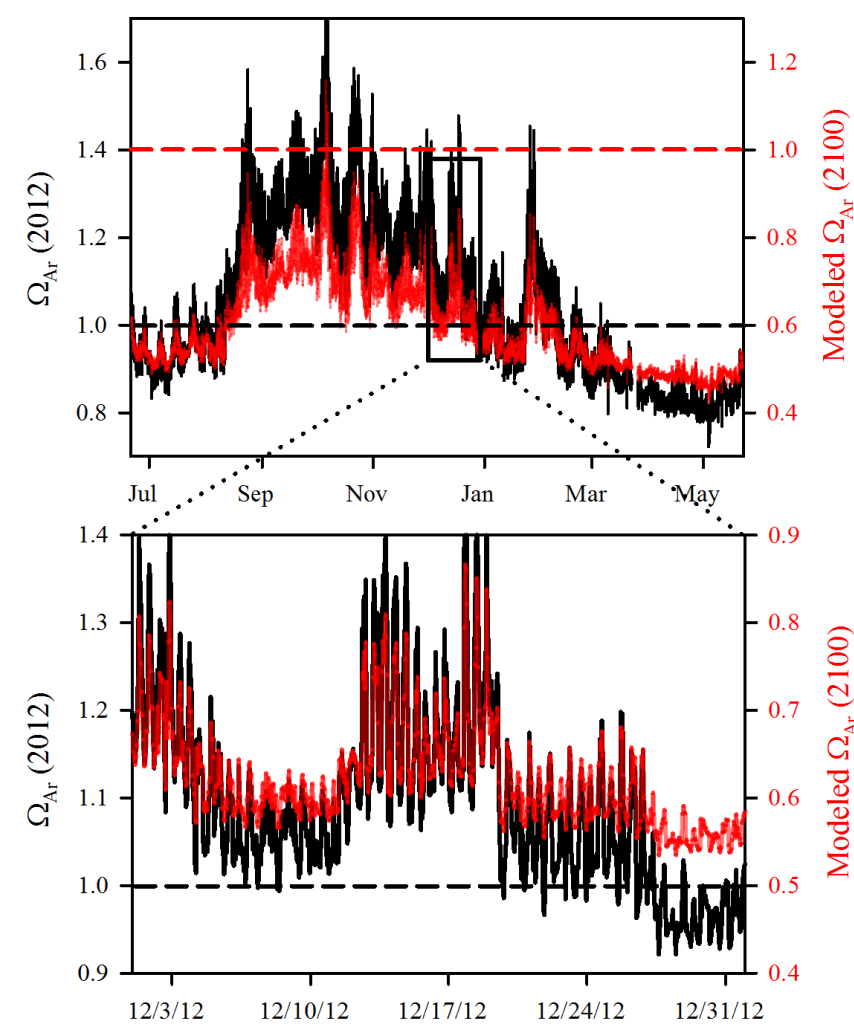

Figure 9. Observed $\Omega_{\mathrm{Ar}}$ in 2012 (black) and modeled $\Omega_{\mathrm{Ar}}$ using the IPCC RCP6.0 scenario for the year 2100 (red) at the shelf break $(88 \mathrm{~m})$ over an annual cycle (top). A close-up for the month of December is shown in the bottom panel. Dashed lines represent $\Omega_{\mathrm{Ar}}=1$. Note that the range, but not the absolute values, of the vertical axes for each figure is the same.

constant rate. The rate of increase in $p \mathrm{CO}_{2}$ is higher than the projected atmospheric $\mathrm{CO}_{2}$ increase at all subsurface sites. This indicates that as ocean acidification progresses, the effects due to elevated $p \mathrm{CO}_{2}$ are more likely to become exacerbated with increasing depth. Mean $\Omega_{\mathrm{Ar}}$ is projected to be $<1$ at the shelf break by 2020 and leave the 2012 variability envelope around 2070.

\section{Discussion}

\subsection{Changes in the buffer factors}

The general patterns of the acidification trajectories presented here can be explained by changing buffer factors of seawater, as deeper sites are more strongly influenced by $\mathrm{CO}_{2}$-rich upwelled waters. The buffer factors $\Pi_{p \mathrm{CO}_{2}}, \Pi_{\mathrm{pH}}$, and $\Pi_{\mathrm{CO}_{3}}$, are defined as

$\Pi_{p \mathrm{CO}_{2}}=\frac{\partial p \mathrm{CO}_{2}}{\partial \mathrm{DIC}}, \Pi_{\mathrm{pH}}=\frac{\partial \mathrm{pH}}{\partial \mathrm{DIC}}, \Pi_{\mathrm{CO}_{3}}=\frac{\partial \mathrm{CO}_{3}^{2-}}{\partial \mathrm{DIC}}$,

representing the change in each carbonate parameter with respect to a change in DIC (Frankignoulle, 1994). The ef- 

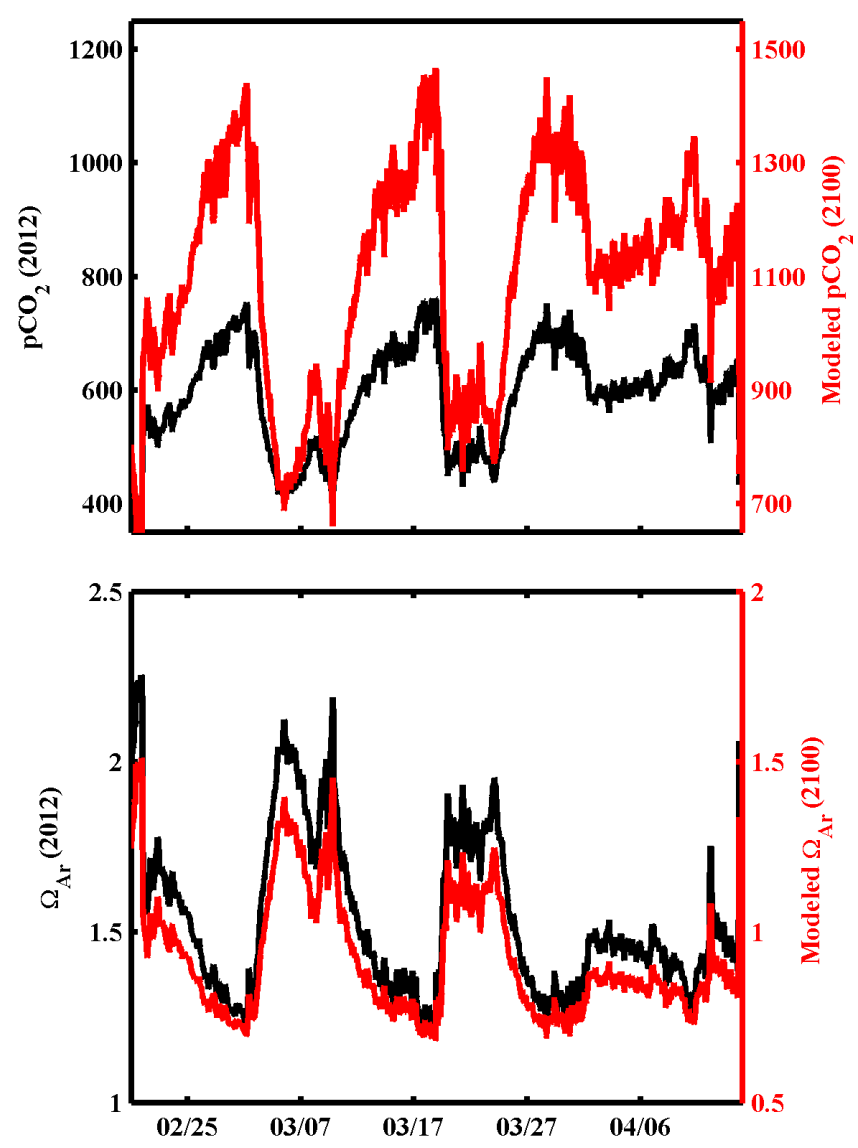

Figure 10. Observed (black) and modeled (red) $p \mathrm{CO}_{2}$ (top) and $\Omega_{\mathrm{Ar}}$ (bottom) at the La Jolla kelp forest $(17 \mathrm{~m})$. Modeled values correspond to projected values in 2100 using the IPCC RCP6.0 scenario. Note that the range, but not the absolute values, of the vertical axes for each figure is the same.

fect of temperature on $\Pi$ is small $(<10 \%)$ between 0 and $15^{\circ} \mathrm{C}$ for the DIC and TA values observed here; thus subsequent values were calculated assuming a temperature of $10^{\circ} \mathrm{C}, \mathrm{TA}=2240 \mu \mathrm{mol} \mathrm{kg}{ }^{-1}$, and salinity $=33.5$ (Fig. 13). The ability for seawater to buffer changes in $p \mathrm{CO}_{2}$ diminishes under higher concentrations of DIC. For example, $\Pi_{p \mathrm{CO}_{2}}$ increases from 1.6 to 3.3 at the surface between 2012 and 2100 under the RCP6.0 scenario. However, since deeper waters are naturally elevated in DIC, this effect is more pronounced at the shelf break: $\Pi_{p \mathrm{CO}_{2}}$ increases from 6.2 to 12.3 during the same time interval. This explains why the surf zone had the lowest mean increase in $p \mathrm{CO}_{2}(225 \mu \mathrm{atm}) \mathrm{de}-$ spite having the highest increase in DIC $\left(82 \mu \mathrm{mol} \mathrm{kg}{ }^{-1}\right)$ out of all of the sites. The shelf break, on the other hand, had the highest increase in $p \mathrm{CO}_{2}(737 \mu \mathrm{atm})$ while having the smallest increase in mean DIC $\left(77 \mu \mathrm{mol} \mathrm{kg}^{-1}\right)$ during the same time period. Furthermore, the increase in variability with depth can be explained as well, as the same biological and physical forcings on tidal to seasonal cycles cause a larger change in $p \mathrm{CO}_{2}$.
Changes in $\Pi_{\mathrm{CO}_{3}}$ can explain the patterns for $\Omega_{\mathrm{Ar}}$, since $\left[\mathrm{Ca}^{2+}\right]$ and $\mathrm{K}_{\mathrm{SP}}$ remain unchanged. Unlike $\Pi_{p \mathrm{CO}_{2}},\left|\Pi_{\mathrm{CO}_{3}}\right|$ decreases at higher concentrations of DIC (Fig. 13b); $\left|\Pi_{\mathrm{CO}_{3}}\right|$ decreases from 0.62 to 0.57 at the surface, and 0.49 to 0.3 at $88 \mathrm{~m}$ between 2012 and 2100 . This change in $\Pi_{\mathrm{CO}_{3}}$ explains the decrease in both the rate and range of $\Omega_{\mathrm{Ar}}$ as anthropogenic $\mathrm{CO}_{2}$ continues to infiltrate the ocean.

The $\Pi_{\mathrm{pH}}$ follows a parabolic shape, where there is a maximum decrease in $\mathrm{pH}$ per DIC added (Fig. 13c). In a pure carbonate solution, this maximum occurs when $\mathrm{DIC}=\mathrm{TA}$, but in seawater it occurs at slightly lower DIC (Frankignoulle, 1994); this maxima occurs at DIC $=2225 \mu \mathrm{mol} \mathrm{kg}^{-1}$ using the parameters listed above. Therefore we would expect to see a similar trend to $p \mathrm{CO}_{2}$ for $\mathrm{pH}$ in which greatest changes occur at depth relative to the surface as long as the mean DIC is lower than this threshold. This condition is only met at the shelf break $(88 \mathrm{~m})$ near the end of the century; thus, as expected, a greater decrease in mean $\mathrm{pH}$ and increase in variability (i.e., SD) was observed with depth (Table 2). One exception was observed where the SD decreased as ocean acidification progressed at the shelf break. This is because an increased proportion of time is spent at greater DIC where $\Pi_{\mathrm{pH}}$ is past its maxima, leading to a smaller variability in $\mathrm{pH}$ under the same changes in DIC. It is important to note that the buffer factor of $\mathrm{H}^{+}\left(\Pi_{\mathrm{H}+}\right)$ follows a similar pattern to $p \mathrm{CO}_{2}$, where it continues to increase as DIC increases (Fig. 13d). Therefore the rate of increase of $\left[\mathrm{H}^{+}\right]$will continue to increase as ocean acidification progresses, and thus biological responses to $\left[\mathrm{H}^{+}\right]$may become exacerbated in the future.

\subsection{Observed and modeled carbonate chemistry variability}

The carbonate conditions presented here are consistent with previous studies. For example, at the shelf break, $\Omega_{\mathrm{Ar}}$ had a strong seasonal cycle, and undersaturated waters were observed almost continuously throughout the upwelling season (Nam et al., 2015), and remained supersaturated for the rest of the year. This is in good agreement with previous hydrographic surveys in this region, where aragoniteundersaturated waters were observed as shallow as $60 \mathrm{~m}$ during the beginning of the upwelling season (Feely et al., 2008) but were not observed in the upper $100 \mathrm{~m}$ at the end of the upwelling season in this region (Bednaršek et al., 2014). Furthermore, estimates based on empirical equations showed a similar seasonal pattern in $\Omega_{\mathrm{Ar}}$ at $88 \mathrm{~m}$, where undersaturated waters were observed every upwelling season (Alin et al., 2012). However, undersaturated waters were not observed in the upper $30 \mathrm{~m}$, unlike northern parts of the CCS where undersaturated conditions are repeatedly observed at the surface during the upwelling season (Bednaršek et al., 2014; Feely et al., 2008; Harris et al., 2013). Due to these traits, the southern portion of the CCS is commonly considered less vulnerable to ocean acidification compared to its 

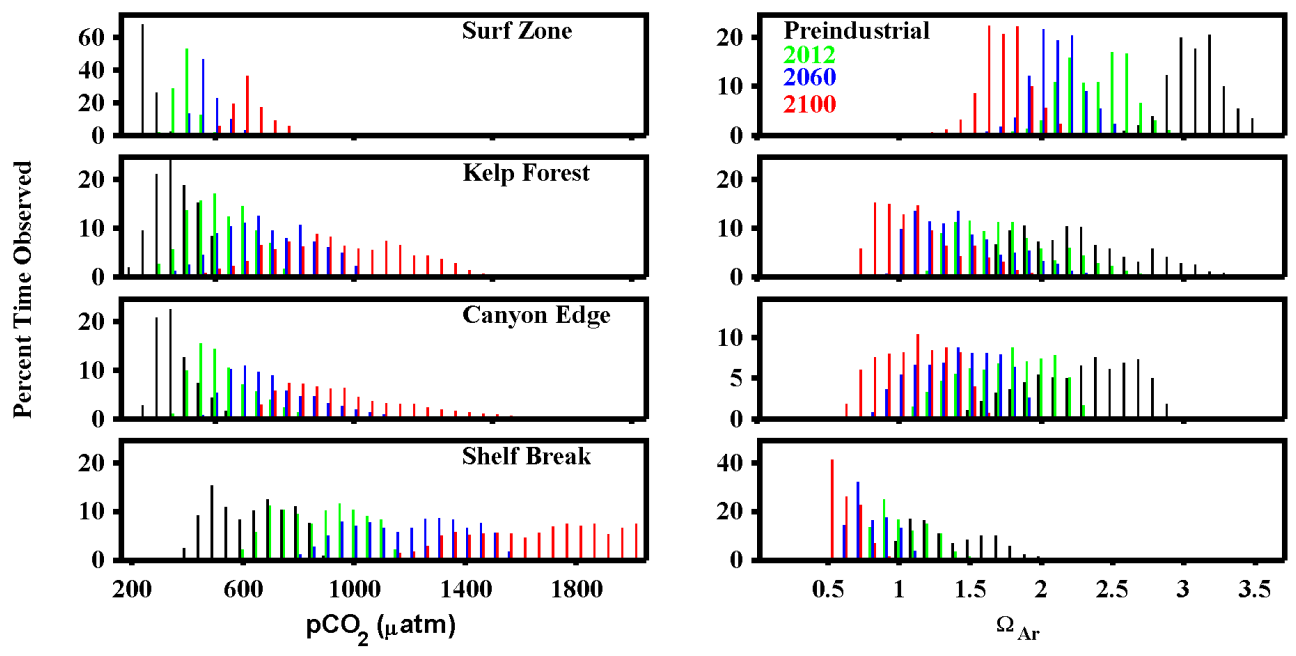

Figure 11. Histogram of modeled $p \mathrm{CO}_{2}$ (left) and $\Omega_{\mathrm{Ar}}$ (right) distribution at the four depths for preindustrial (black), 2012 (green), 2060 (blue), and 2100 (red). Atmospheric $p \mathrm{CO}_{2}$ for the years 2060 and 2100 roughly corresponds to 510 and $670 \mu$ atm based on the IPCC RCP6.0 scenario.
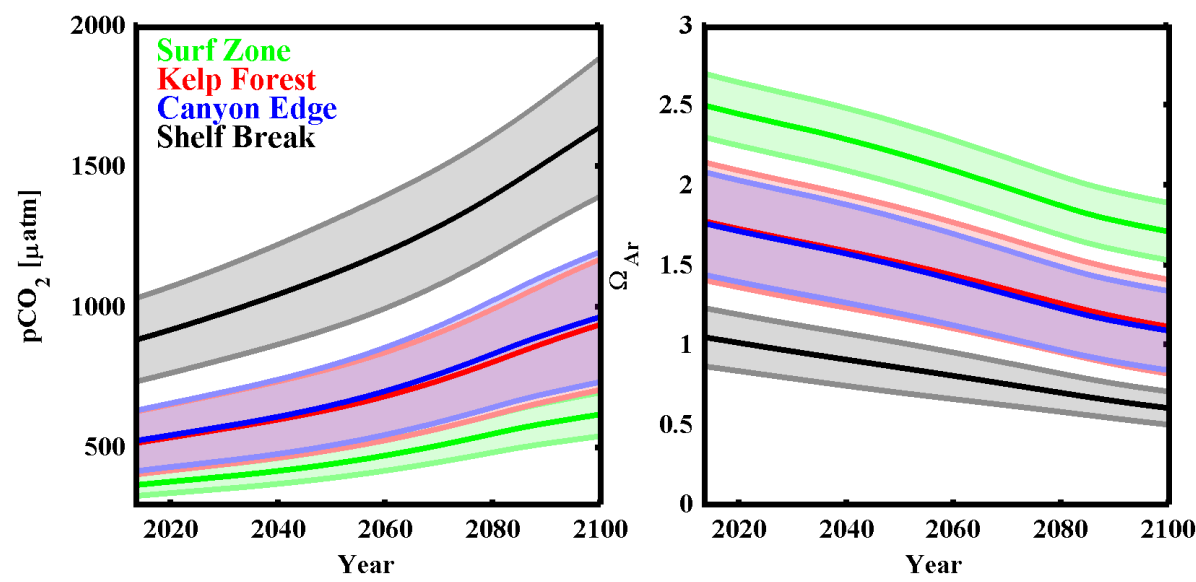

Figure 12. Projected $p \mathrm{CO}_{2}$ (left) and $\Omega_{\mathrm{Ar}}$ (right) between 2013 and 2100 under the IPCC RCP6.0 scenario. The solid line and the shaded region represent the mean and $\pm 1 \mathrm{SD}$, respectively.

northern counterpart. However, our results demonstrate that $\Omega_{\mathrm{Ar}}$ as low as 1.3 is routinely observed in the kelp forest $(17 \mathrm{~m})$, demonstrating the imminent threat of anthropogenic ocean acidification to the southern CCS.

The subsurface habitats characterized in this study routinely experience $\Omega_{\mathrm{Ar}}$ conditions that have been shown to have non-lethal chronic effects on various bivalve larvae between $\Omega_{\mathrm{Ar}}$ of 1.2 and 2.0 (Barton et al., 2012; Gaylord et al., 2011; Gazeau et al., 2011; Hettinger et al., 2012; Waldbusser et al., 2015). However, the length of exposure to these unfavorable conditions varies between habitats. For example, the organisms in the kelp forest would be exposed to low- $\Omega_{\mathrm{Ar}}$ conditions for days to weeks, whereas large tidal variability at the canyon edge could result in periodic exposure to low$\Omega_{\mathrm{Ar}}$ conditions on the order of hours. Therefore the effects of low $\Omega_{\text {Ar }}$ will largely depend on the reproductive timing and environmental variability that occur on event to seasonal timescales; the effects of exposure on various timescales are poorly understood. Such events are expected to become more severe in the future (Hauri et al., 2013a) and thus could lead to an increased rate of failed recruitment of bivalves and other keystone organisms (Byrne et al., 2013).

It may be surprising that the mean diel range of $\mathrm{pH}$ was the smallest at the kelp forest (Table 3), as one might expect a large diel cycle driven by photosynthesis and respiration in a highly productive kelp forest. This is most likely because the sensor was deployed near the benthos, below the most productive region of the forest. Frieder et al. (2012) observed significantly larger diel $\mathrm{pH}$ variability closer to the surface (7 $\mathrm{m}$ depth) compared to near the bottom (17 $\mathrm{m}$ depth; same as this study), demonstrating that the biologically driven diel cycle diminishes with increasing depth within the canopy. 

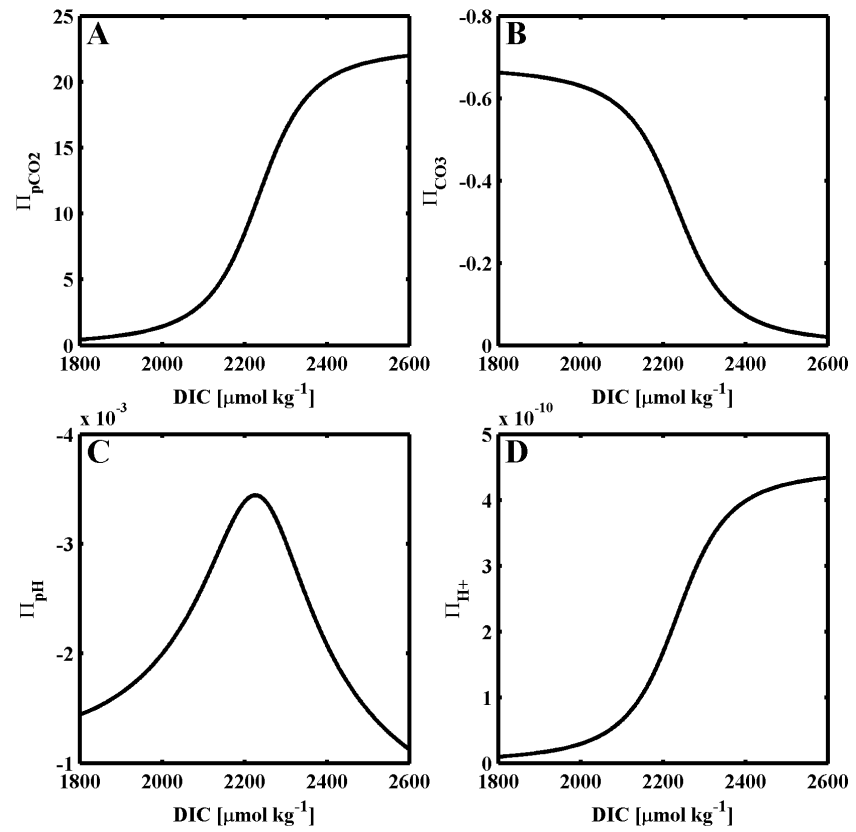

Figure 13. Buffer factor $\Pi$ for $p \mathrm{CO}_{2}$ (a), $\mathrm{CO}_{3}^{2-}$ (b), $\mathrm{pH}$ (c), and $\left[\mathrm{H}^{+}\right]$(d) as a function of DIC. Note the inverted $y$ axis in panels (b) and (c). Model parameters to calculate the $\Pi$ values were $\mathrm{TA}=2240 \mu \mathrm{mol} \mathrm{kg}-1$, temperature $=10^{\circ} \mathrm{C}$, salinity $=33.5$, pressure $=1.013$ bar.

Therefore it is important to keep in mind that the results presented here are not reflecting kelp forest production dynamics but rather conditions that are experienced by benthic dwelling organisms inside the kelp forest.

The trajectories are sensitive to the choice of the emission scenario (Fig. 14). Trends are similar at all depths; thus only the mean $p \mathrm{CO}_{2}$ and $\Omega_{\mathrm{Ar}}$ projections at the shelf break are shown in Fig. 14. The highest emission scenario (RCP8.5) diverges from the two intermediate scenarios around 2030, while the lowest emission scenario (RCP2.6) diverges around 2050. The two intermediate scenarios (RCP4.5 and RCP6.0) do not diverge significantly until 2070 . The delayed response to different atmospheric $\mathrm{CO}_{2}$ trajectories occurs because upwelled waters have spent several decades since they were last in contact with the atmosphere (Feely et al., 2008). Therefore the anthropogenic ocean acidification trajectory for the SCB is already determined for the next several decades, and any mitigation due to changing $\mathrm{CO}_{2}$ emissions will be delayed.

The results presented here are site-specific, and they do not necessarily reflect conditions at all kelp forests, canyon edges, and shelf breaks. However, if sensor $\mathrm{pH}$ data and corresponding regional hydrographic surveys are available, then a $\Delta \mathrm{DIC}_{\mathrm{anth}}-\sigma_{\theta}$ relationship can be established for that region and applied to the sensor data. For example, this approach can potentially expanded to many regions for the CCS, using the North American Carbon Program West Coast Cruise (Feely et al., 2008) and the $\Delta \mathrm{DIC}_{\text {diseq }}$ for the Pacific Ocean
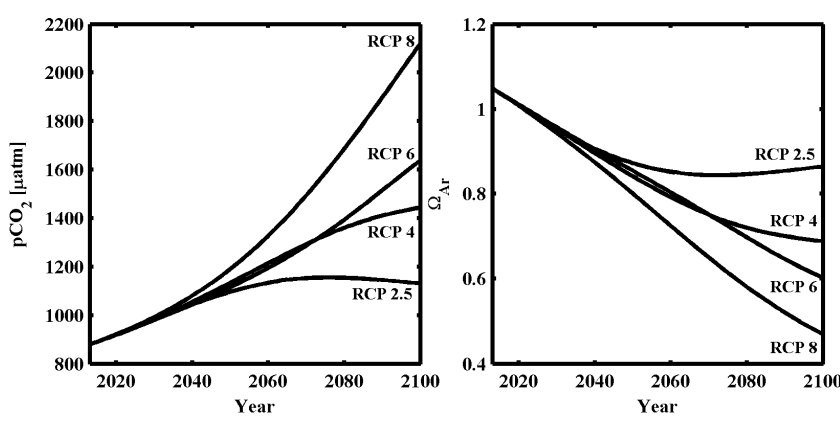

Figure 14. Projections of mean $p \mathrm{CO}_{2}$ (left) and $\Omega_{\mathrm{Ar}}$ (right) at the shelf break $(88 \mathrm{~m})$ based on four projections from the Fifth Assessment of the IPCC.

(Sabine et al., 2002). If similar data exist, then this approach can be expanded to other upwelling margins as well.

The SCB experiences a steady but weaker degree of upwelling compared to the northern regions of the CCS, where upwelling events are more pronounced (Bograd et al., 2009). These regions could experience more extreme conditions regularly, as well as significantly higher variability in carbonate conditions (Harris et al., 2013). However, such dynamics are poorly understood, and more high-frequency observations of carbonate parameters along this system are needed. Source water properties must be characterized through hydrographic surveys. Alternatively, for regions where such data for source waters are not available, sensor data can be combined with either global circulation model or ROMS outputs. This approach will alleviate the cost associated with characterizing source waters and, to a large degree, incorporate processes such as interannual variability, decadal changes in source water properties, and reduced ventilation. It is critical that inorganic carbon sensors (e.g., $\mathrm{pH}$ or $p \mathrm{CO}_{2}$ ) are colocated with basic physical oceanographic measurements (e.g., $T$ and $S$ ) to determine source water properties especially for subsurface deployments.

\subsection{Model assessment}

The sensitivity of the projected carbonate conditions to the assumptions made in the model is explored here. For example, temperatures observed in 2012 were used to parameterize the model. Sea surface temperature has increased over the past century due to climate change (Smith et al., 2008), and is expected to continue. This will affect the $\mathrm{CO}_{2}$ equilibrium concentration $\left(\mathrm{DIC}_{\mathrm{eq}}\right)$, but the effects are small and will reduce $\mathrm{DIC}_{\mathrm{eq}}$ by only several $\mu \mathrm{mol} \mathrm{kg}{ }^{-1}$. Both $p \mathrm{CO}_{2}$ and $\Omega_{\mathrm{Ar}}$ are dependent on in situ temperature; the effects on $\Omega_{\mathrm{Ar}}$ are negligible $\left(\Delta \Omega / \Delta T<0.01^{\circ} \mathrm{C}^{-1}\right)$, whereas $\Delta p \mathrm{CO}_{2} / \Delta T$ increases at higher $p \mathrm{CO}_{2}$ levels, and can be as large as $60 \mu a \mathrm{~atm}^{\circ} \mathrm{C}^{-1}$ at the end of the century, compared to $30 \mu a \mathrm{~atm}^{\circ} \mathrm{C}^{-1}$ at present day at the shelf break. These temperature dependencies will affect the mean conditions, but the magnitude of the variability will be relatively unaffected. 
However, it should be noted that this simple error analysis does not include any biological feedbacks that increased temperature or $\mathrm{CO}_{2}$ may induce. For example, phase shifts from kelp-dominated to algal turfs might be an outcome of sea surface warming and acidification (Connell and Russell, 2010), with implications for habitat-scale biogeochemical cycling. Likewise, higher temperatures may increase remineralization rates along the path of the subducted water (Rivkin and Legendre, 2001), further enhancing acidification.

TA conditions from 2012 were used to calculate $p \mathrm{CO}_{2}$ and $\Omega_{\mathrm{Ar}}$ for all years. Changes in TA affect the buffer factors of seawater; thus, alterations in TA distribution will either speed up or slow down the progression of ocean acidification. However, trends in TA along the CCS on decadal timescales are unknown due to insufficient data. Reduced ventilation in high-latitude seas, altered precipitation patterns, and changes in surface calcification and water-column dissolution rates would all lead to changes in upwelled TA conditions (Fassbender et al., 2011; Lee et al., 2006). Quantifying these processes is difficult and out of the scope of this study. Nevertheless, to demonstrate the magnitude of the uncertainty due to TA, $p \mathrm{CO}_{2}$ was projected for the year 2100 with a $+20 \mu \mathrm{mol} \mathrm{kg}{ }^{-1}$ bias to TA. The effects were strongly dependent on depth: mean $p \mathrm{CO}_{2}$ was reduced by approximately 240,130 , and $70 \mu \mathrm{atm}$ at $88 \mathrm{~m}, 30 \mathrm{~m}$, and the surface, respectively.

Finally, the model presented here projects future carbonate conditions by assuming that the dynamics that control the variability at each habitat (e.g., seasonal and episodic upwelling events, internal waves and tides, and biological production and respiration) remain the same as 2012 conditions, and it does not account for any variability that occurs on interannual to decadal timescales. For example, changes in $\mathrm{O}_{2}$ and $\mathrm{pH}$ on the continental shelf associated with interannual climate events, such as El Niño, have been observed (Nam et al., 2011). However, since 2012 did not correspond with a strong El Niño or La Niña phase, we believe that it was not strongly biased by such events. Furthermore, recent evidence suggests that the proportion of Pacific Equatorial Waters in the California Undercurrent has been increasing over the past several decades, thus modifying the source water properties for upwelled waters onto the continental shelf (Bograd et al., 2015). Since waters of equatorial origin observed between 100 and $500 \mathrm{~m}$ are elevated in DIC and lower in $\mathrm{O}_{2}$ (Bograd et al., 2015), it is expected that the SCB will experience higher levels of acidification than predicted from this study if this redistribution of water masses of equatorial origin continues. However, at this time, we lack observations with sufficient longevity to predict how climate variability on interannual to decadal timescales might modify the acidification trajectory over the course of the next century. Sustained, high-frequency time series of inorganic carbon parameters are required to elucidate such effects.

\subsection{Implications for ocean acidification research}

In order to properly assess the impacts of anthropogenic ocean acidification through laboratory manipulation experiments, the control and experimental conditions should accurately reflect the study organism's present-day and future habitat conditions (McElhany and Busch, 2013; Reum et al., 2015). The most common control treatment used in ocean acidification experiments for organisms found in the CCS was a $p \mathrm{CO}_{2}$ value of $\sim 400 \mu$ atm, reflecting atmospheric conditions (compiled by Reum et al., 2015). However, our sensor data showed that all subsurface habitats had significantly greater $p \mathrm{CO}_{2}$ relative to the atmosphere (Table 2). For example, the mean $p \mathrm{CO}_{2}$ at the kelp forest is about $100 \mu \mathrm{atm}$ greater than the atmosphere and routinely experiences conditions of more than $300 \mu \mathrm{atm}$ above atmospheric. Therefore utilizing atmospheric $p \mathrm{CO}_{2}$ conditions for control treatments will necessarily underestimate the baseline $p \mathrm{CO}_{2}$ for organisms collected from subsurface habitats.

Recent studies that incorporate natural variability into ocean acidification experiments observed modified responses relative to constant conditions (Dufault et al., 2012; Frieder et al., 2014). However, the effect of natural variability on organismal response to ocean acidification, especially through various life stages is still poorly understood. Our model results demonstrate that variability trajectories are also habitatspecific. For example, in the kelp forest, the variability, approximated by the SD, was $93 \mu$ atm in 2012, whereas this increased to $202 \mu \mathrm{atm}$ in 2100 (Table 2). Furthermore, despite having similar mean $\mathrm{CO}_{2}$ conditions, the largest variability was observed on event timescales in the kelp forest, whereas the dominant variability occurred on tidal and seasonal cycles at the canyon edge. Therefore future ocean acidification studies investigating the effect of natural variability should not only incorporate increasing magnitude into their experimental design but also consider variability patterns on appropriate timescales.

Temperature and $\mathrm{O}_{2}$ were tightly correlated with carbonate parameters across habitats and various timescales (daily to seasonal) in this study (Fig. 15); similar correlation has been documented across the CCS in general (Reum et al., $2014,2015)$. These parameters can potentially act as additional stressors (Padilla-Gamiño et al., 2013) or stress reliefs (Gooding et al., 2009) for ocean acidification. However, laboratory experiments incorporating the effects of temperature (Gooding et al., 2009; Padilla-Gamiño et al., 2013) and $\mathrm{O}_{2}$ (Frieder et al., 2014) have just started to be explored for the CCS, and no studies have been conducted that incorporate all three variables in their experimental design. Future studies investigating the synergistic effects of $\mathrm{O}_{2}$, temperature, and $\mathrm{CO}_{2}$ should establish experimental conditions based on environmental data (Fig. 15). Although development of systems that can manipulate individual parameters is challenging, important strides have been made to make such experimental setups accessible to the community (Bockmon et al., 

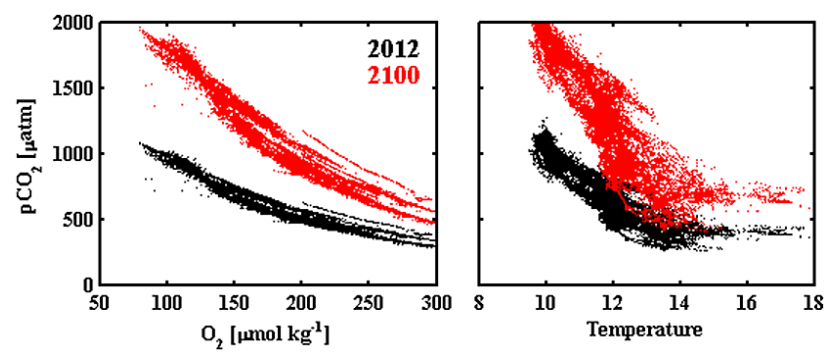

Figure 15. $p \mathrm{CO}_{2}$ as a function of $\mathrm{O}_{2}$ (left) and temperature (right) from the kelp forest and shelf break. Data observed in 2012 and projected for 2100 are plotted.

2013). The development of habitat-specific ocean acidification models provides a link between environment and laboratory to facilitate interpretations of physiological responses to elevated $\mathrm{CO}_{2}$ in the context of current and future environmental conditions.

Discerning habitat-specific $\mathrm{CO}_{2}$ signatures could lead to the discovery of local populations that are more tolerant of future $\mathrm{CO}_{2}$ conditions. For example, large high-frequency variability in $\mathrm{CO}_{2}$ could lead to a greater capacity for physiological and phenotypic plasticity, as organisms are routinely exposed to a wide range of $\mathrm{CO}_{2}$. The embryos of Doryteuthis opalescens, an important fishery species in California, can tolerate low $\mathrm{pH}$ and $\mathrm{O}_{2}$, perhaps due to the fact that they routinely experience a wide range of $\mathrm{pH}$ and $\mathrm{O}_{2}$ (Navarro, 2014). Furthermore, such environmental conditions may be conducive for the existence of highly $\mathrm{CO}_{2}$-tolerant subpopulations, allowing for adaptation to buffer some of the negative effects of ocean acidification (Hofmann and Todgham, 2010). Alternatively, these populations could be living near critical biological thresholds, as has been suggested for the thermal stress of some organisms living in the intertidal (Somero, 2002). A massive failure in an oyster hatchery in Oregon was linked to upwelling of high- $\mathrm{CO}_{2}$ waters during a critical life stage of oyster larvae (Barton et al., 2012), indicating the existence of $\mathrm{CO}_{2}$ thresholds for some marine organisms (Bednaršek et al., 2014). However, such thresholds may be dependent on species, life stage, and/or environmental history. As we begin to realize which populations of species and life stages are living near acidification thresholds versus those that exhibit acidification tolerance, implementation of habitat-specific acidification models can be used as a tool to aid protection, management, and remediation efforts of critical marine habitats now and in the future.

\section{Conclusions}

Here we have presented habitat-specific carbonate chemistry projections for four coastal habitats along an upwelling margin. The projections were generated by combining highfrequency sensor measurements, a regional empirical rela- tionship for TA, hydrographic survey data to quantify sourcewater properties of upwelled waters, and the atmospheric $\mathrm{CO}_{2}$ record. Even though the four habitats were within $5 \mathrm{~km}$ of one another, distinct habitat-specific variability signatures and acidification trajectories were observed. These results reveal the existence of highly variable $\mathrm{CO}_{2}$ signatures within a small geographic area, and the potential for discoveries of habitats that could act as refugia from ocean acidification. Changes in the buffer factors largely explained the observed patterns; however, local biological feedbacks could also produce a large acidification signal. In all habitats studied, carbonate conditions have left, or are leaving, preindustrial variability envelopes. Model projections suggest that anthropogenic ocean acidification will continue to progress in the CCS and other upwelling margins over the next several decades regardless of any changes in $\mathrm{CO}_{2}$ emissions; any impacts from reduced emissions will only be observed midcentury and beyond. This demonstrates the urgency of the situation, and this delayed response must be taken into account when assessing the impacts of ocean acidification and developing mitigation and monitoring strategies.

\section{The Supplement related to this article is available online at doi:10.5194/bg-12-5853-2015-supplement.}

Acknowledgements. Hydrographic data and kelp forest time series data are available from the BCO-DMO project SeapHOx (http:// www.bco-dmo.org/project/2122). Sensor time series data are available for the Del Mar buoy at http://mooring.ucsd.edu, and upon request for the Scripps Pier (smithj@ucsd.edu).

We would like to thank the University of California Ship Funds for providing ship time for maintenance of the Del Mar buoy and the San Diego Coastal Expedition cruises. We thank Emily Kelly for DIC analysis at sea, as well as all of the ship crew and volunteers who aided in sample collection. We would like to thank Emily Donham for providing discrete TA data from the kelp forest. The Del Mar buoy platform is maintained by the Ocean Time-series Group (http://mooring.ucsd.edu); we acknowledge their efforts to continuously collect and maintain the time series data. The canyon edge deployment was supported by the NOAA (grant \#NA10OAR4170060) and the California Sea Grant College Program (project \#R/CC-04). The kelp forest deployment was supported through NSF-OCE award no. 0927445. We would also like to thank the Ellen Browning Scripps Foundation, the Scripps Family Foundation, the Bohn and Grand families, and the California State Water Board for financial support for the Scripps Ocean Acidification Real-time Monitoring Program. S. Nam was partly supported by the Research Resettlement Fund for the new faculty of Seoul National University and Korean Ministry of Oceans and Fisheries through the EAST-I program. Financial support for R. A. Feely was provided by NOAA under the NOAA Ocean Acidification Program and the Climate Observations Division of the NOAA Climate Program, contribution number 4313 from the NOAA Pacific Marine Environmental Laboratory. The 
statements, findings, conclusions, and recommendations are those of the authors and do not necessarily reflect the views of California Sea Grant, state agencies, NOAA, NSF, or the US Department of Commerce.

Edited by: C. P. Slomp

\section{References}

Alin, S. R., Feely, R. A., Dickson, A. G., Hernández-Ayón, J. M., Juranek, L. W., Ohman, M. D., and Goericke, R.: Robust empirical relationships for estimating the carbonate system in the southern California Current System and application to CalCOFI hydrographic cruise data (2005-2011), J. Geophys. Res., 117, C05033, doi:10.1029/2011JC007511, 2012.

Anderson, L. A. and Sarmiento, J. L.: Redfield ratios of remineralization determined by nutrient data analysis, Global Biogeochem. Cy., 8, 65-80, 1994.

Andersson, A. J., Yeakel, K. L., Bates, N. R., and de Putron, S. J.: Partial offsets in ocean acidification from changing coral reef biogeochemistry, Nat. Clim. Change, 3, 1-6, 2013.

Barton, A., Hales, B., Waldbusser, G. G., Langdon, C., and Feely, R. A.: The Pacific oyster, Crassostrea gigas, shows negative correlation to naturally elevated carbon dioxide levels: Implications for near-term ocean acidification effects, Limnol. Oceanogr., 57, 698-710, 2012.

Bates, N. R., Astor, Y. M., Church, M. J., Currie, K., Dore, J. E., Gonzalez-Davila, M., Lorenzoni, L., Muller-Karger, F., Olafsson, J., and Santana-Casiano, J. M.: A time-series view of changing surface ocean chemistry due to ocean uptake of anthropogenic $\mathrm{CO}_{2}$ and ocean acidification, Oceanography, 27, 126141, 2014.

Bednaršek, N., Feely, R. A., Reum, J. C. P., Peterson, B., Menkel, J., Alin, S. R., and Hales, B.: Limacina helicina shell dissolution as an indicator of declining habitat suitability owing to ocean acidification in the California Current Ecosystem, Proc. R. Soc. B Biol. Sci., 281, 20140123, doi:10.1098/rspb.2014.0123, 2014.

Bockmon, E. E., Frieder, C. A., Navarro, M. O., White-Kershek, L. A., and Dickson, A. G.: Technical note: controlled experimental aquarium system for multi-stressor investigation of carbonate chemistry, oxygen saturation, and temperature, Biogeosciences, 10, 5967-5975, doi:10.5194/bg-10-5967-2013, 2013.

Bograd, S. J., Schroeder, I., Sarkar, N., Qiu, X., Sydeman, W. J., and Schwing, F. B.: Phenology of coastal upwelling in the California Current, Geophys. Res. Lett., 36, 1-5, 2009.

Bograd, S. J., Buil, M. P., Lorenzo, E. Di, Castro, C. G., Schroeder, I. D., Goericke, R., Anderson, C. R., Benitez-Nelson, C., and Whitney, F. A.: Changes in source waters to the Southern California Bight, Deep Sea Res. Pt. II, 112, 42-52, 2015.

Booth, J. A. T., McPhee-Shaw, E. E., Chua, P., Kingsley, E., Denny, M., Phillips, R., Bograd, S. J., Zeidberg, L. D., and Gilly, W. F.: Natural intrusions of hypoxic, low $\mathrm{pH}$ water into nearshore marine environments on the California coast, Cont. Shelf Res., 45, 108-115, 2012.

Bresnahan, P. J., Martz, T. R., Takeshita, Y., Johnson, K. S., and LaShomb, M.: Best practices for autonomous measurement of seawater $\mathrm{pH}$ with the Honeywell Durafet, Methods Oceanogr., 9, 44-60, 2014.
Brewer, P. G. and Peltzer, E. T.: Limits to marine life, Science, 324, 347-348, 2009.

Byrne, M., Lamare, M., Winter, D., Dworjanyn, S. A., and Uthicke, S.: The stunting effect of a high $\mathrm{CO}_{2}$ ocean on calcification and development in sea urchin larvae, a synthesis from the tropics to the poles, Philos. Trans. R. Soc. B Biol. Sci., 368, 1-13, 2013.

Byrne, R. H., Mecking, S., Feely, R. A., and Liu, X.: Direct observations of basin-wide acidification of the North Pacific Ocean, Geophys. Res. Lett., 37, 1-5, 2010.

Cai, W.-J., Hu, X., Huang, W.-J., Murrell, M. C., Lehrter, J. C., Lohrenz, S. E., Chou, W.-C., Zhai, W., Hollibaugh, J. T., Wang, Y., Zhao, P., Guo, X., Gundersen, K., Dai, M., and Gong, G.-C.: Acidification of subsurface coastal waters enhanced by eutrophication, Nat. Geosci., 4, 766-770, 2011.

Carter, B. R., Radich, J. A., Doyle, H. L., and Dickson, A. G.: An automated system for spectrophotometric seawater $\mathrm{pH}$ measurements, Limnol. Oceanogr. Methods, 11, 16-27, 2013.

Clayton, T. D. and Byrne, R. H.: Spectrophotometric seawater $\mathrm{pH}$ measurements: total hydrogen ion concentration scale calibration of m-cresol purple and at-sea results, Deep Sea Res. Pt. I, 40, 2115-2129, 1993.

Connell, S. D. and Russell, B. D.: The direct effects of increasing $\mathrm{CO}_{2}$ and temperature on non-calcifying organisms: increasing the potential for phase shifts in kelp forests., Proc. Biol. Sci., 277, 1409-1415, 2010.

Dickson, A. G., Sabine, C. L., and Christian, J. R., Eds.: Guide to best practices for ocean CO2 measurements, PICES Special Publication 3, 2007.

Duarte, C. M., Hendriks, I. E., Moore, T. S., Olsen, Y. S., Steckbauer, A., Ramajo, L., Carstensen, J., Trotter, J. A., and McCulloch, M.: Is ocean acidification an open-ocean syndrome? Understanding anthropogenic impacts on seawater $\mathrm{pH}$, Estuaries and Coasts, 36, 221-236, 2013.

Dufault, A. M., Cumbo, V. R., Fan, T.-Y., and Edmunds, P. J.: Effects of diurnally oscillating $p \mathrm{CO} 2$ on the calcification and survival of coral recruits, Proc. R. Soc. B Biol. Sci., 279, 29512958, 2012.

Emerson, S. R.: Accurate measurement of $\mathrm{O}_{2}, \mathrm{~N}_{2}$, and Ar gases in water and the solubility of $\mathrm{N}_{2}$, Mar. Chem., 64, 337-347, 1999.

Fassbender, A. J., Sabine, C. L., Feely, R. A., Langdon, C., and Mordy, C. W.: Inorganic carbon dynamics during northern California coastal upwelling, Cont. Shelf Res., 31, 1180-1192, 2011.

Feely, R. A., Sabine, C. L., Hernandez-Ayon, J. M., Ianson, D., and Hales, B.: Evidence for upwelling of corrosive "acidified" water onto the continental shelf, Science, 320, 1490-1492, 2008.

Feely, R. A., Doney, S. C., and Cooley, S. R.: Ocean acidification: present conditions and future changes in a high- $\mathrm{CO}_{2}$ world, Oceanography, 22, 36-47, 2009.

Feely, R. A., Alin, S. R., Newton, J., Sabine, C. L., Warner, M., Devol, A., Krembs, C., and Maloy, C.: The combined effects of ocean acidification, mixing, and respiration on $\mathrm{pH}$ and carbonate saturation in an urbanized estuary, Estuar. Coast. Shelf Sci., 88, 442-449, 2010.

Frankignoulle, M.: A complete set of buffer factors for acid/base $\mathrm{CO}_{2}$ system in seawater, J. Mar. Syst., 5, 111-118, 1994.

Frieder, C. A., Nam, S., Martz, T. R., and Levin, L. A.: High temporal and spatial variability of dissolved oxygen and $\mathrm{pH}$ in a nearshore California kelp forest, Biogeosciences, 9, 3917-3930, doi:10.5194/bg-9-3917-2012, 2012. 
Frieder, C. A., Gonzalez, J. P., Bockmon, E. E., Navarro, M. O., and Levin, L. A.: Can variable $\mathrm{pH}$ and low oxygen moderate ocean acidification outcomes for mussel larvae?, Glob. Change Biol., 20, 754-64, 2014.

Friederich, G. E., Walz, P. M., Burczynski, M. G., and Chavez, F. P.: Inorganic carbon in the central California upwelling system during the 1997-1999 El Niño-La Niña event, Prog. Oceanogr., 54, 185-203, 2002.

Garcia, H. E. and Gordon, L. I.: Oxygen solubility in seawater: better fitting equations, Limnol. Oceanogr., 37, 1307-1312, 1992.

Gaylord, B., Hill, T. M., Sanford, E., Lenz, E. A., Jacobs, L. A., Sato, K. N., Russell, A. D., and Hettinger, A.: Functional impacts of ocean acidification in an ecologically critical foundation species, J. Exp. Biol., 214, 2586-2594, 2011.

Gazeau, F., Gattuso, J.-P., Greaves, M., Elderfield, H., Peene, J., Heip, C. H. R., and Middelburg, J. J.: Effect of carbonate chemistry alteration on the early embryonic development of the Pacific oyster (Crassostrea gigas), PLoS One, 6, e23010, doi:10.1371/journal.pone.0023010, 2011.

Gooding, R. A., Harley, C. D. G., and Tang, E.: Elevated water temperature and carbon dioxide concentration increase the growth of a keystone echinoderm, Proc. Natl. Acad. Sci. USA, 106, 93169321, 2009.

Gruber, N., Sarmiento, J. L., and Stocker, T. F.: An improved method for detecting anthropogenic $\mathrm{CO}_{2}$ in the oceans, Global Biogeochem. Cy., 10, 809-837, 1996.

Gruber, N., Lachkar, Z., Frenzel, H., Marchesiello, P., Münnich, M., McWilliams, J. C., Nagai, T., and Plattner, G.-K.: Eddy-induced reduction of biological production in eastern boundary upwelling systems, Nat. Geosci., 4, 787-792, 2011.

Gruber, N., Hauri, C., Lachkar, Z., Loher, D., Frölicher, T. L., and Plattner, G.-K.: Rapid progression of ocean acidification in the California Current System, Science, 337, 220-223, 2012.

Hales, B., Takahashi, T., and Bandstra, L.: Atmospheric $\mathrm{CO}_{2}$ uptake by a coastal upwelling system, Global Biogeochem. Cy., 19, 111, 2005.

Hall-Spencer, J. M., Rodolfo-Metalpa, R., Martin, S., Ransome, E., Fine, M., Turner, S. M., Rowley, S. J., Tedesco, D., and Buia, M.-C.: Volcanic carbon dioxide vents show ecosystem effects of ocean acidification, Nature, 454, 96-99, 2008.

Harris, K. E., DeGrandpre, M. D., and Hales, B.: Aragonite saturation state dynamics in a coastal upwelling zone, Geophys. Res. Lett., 40, 2720-2725, 2013.

Hauri, C., Gruber, N., McDonnell, A. M. P., and Vogt, M.: The intensity, duration, and severity of low aragonite saturation state events on the California continental shelf, Geophys. Res. Lett., 40, 3424-3428, 2013a.

Hauri, C., Gruber, N., Vogt, M., Doney, S. C., Feely, R. A., Lachkar, Z., Leinweber, A., McDonnell, A. M. P., Munnich, M., and Plattner, G.-K.: Spatiotemporal variability and long-term trends of ocean acidification in the California Current System, Biogeosciences, 10, 193-216, doi:10.5194/bg-10-193-2013, 2013b.

Hettinger, A., Sanford, E., Hill, T. M., Russell, A. D., Sato, K. N. S., Hoey, J., Forsch, M., Page, H. N., and Gaylord, B.: Persistent carry-over effects of planktonic exposure to ocean acidification in the Olympia oyster, Ecology, 93, 2758-2768, 2012.

Hijioka, Y., Matsuoka, Y., Nishimoto, H., Masui, M., and Kainuma, M.: Global GHG emissions scenarios under GHG concentration stabilization targets, J. Glob. Environ. Eng., 13, 97-108, 2008.
Hofmann, G. E. and Todgham, A. E.: Living in the now: physiological mechanisms to tolerate a rapidly changing environment, Annu. Rev. Physiol., 72, 127-45, 2010.

Hofmann, G. E., Smith, J. E., Johnson, K. S., Send, U., Levin, L. A., Micheli, F., Paytan, A., Price, N. N., Peterson, B., Takeshita, Y., Matson, P. G., Crook, E. D., Kroeker, K. J., Gambi, M. C., Rivest, E. B., Frieder, C. A., Yu, P. C., and Martz, T. R.: High-frequency dynamics of ocean $\mathrm{pH}$ : a multi-ecosystem comparison, edited by: Chin, W.-C., PLoS One, 6, e28983, doi:10.1371/journal.pone.0028983, 2011.

Hofmann, G. E., Evans, T. G., Kelly, M. W., Padilla-Gamiño, J. L., Blanchette, C. A., Washburn, L., Chan, F., McManus, M. A., Menge, B. A., Gaylord, B., Hill, T. M., Sanford, E., LaVigne, M., Rose, J. M., Kapsenberg, L., and Dutton, J. M.: Exploring local adaptation and the ocean acidification seascape - studies in the California Current Large Marine Ecosystem, Biogeosciences, 11, 1053-1064, doi:10.5194/bg-11-1053-2014, 2014.

Keeling, C. D., Piper, S. C., Bacastow, R. B., Wahlen, M., Whorf, T. P., Heimann, M., and Meijer, H. A.: Atmospheric $\mathrm{CO}_{2}$ and ${ }^{13} \mathrm{CO}_{2}$ exchange with the terrestrial biosphere and oceans from 1978 to 2000: observations and carbon cycle implications, in: A history of atmospheric $\mathrm{CO}_{2}$ and its effects on plants, animals, and ecosystems, edited by: Ehleringer, J. R., Cerling, T. E., and Dearing, M. D., Springer Verlag, New York, 83-113, 2005.

Kroeker, K. J., Micheli, F., Gambi, M. C., and Martz, T. R.: Divergent ecosystem responses within a benthic marine community to ocean acidification, Proc. Natl. Acad. Sci. USA, 108, 1451514520, 2011.

Langdon, C., Gattuso, J., and Andersson, A.: Measurements of calcification and dissolution of benthic organisms and communities, in Guide to Best Practices for Ocean Acidificaton Research and Data Reporting, Publications Office of the European Union, Luxembourg, 213-232, 2010.

Lauvset, S. K. and Gruber, N.: Long-term trends in surface ocean pH in the North Atlantic, Mar. Chem., 162, 71-76, 2014.

Lee, K., Tong, L. T., Millero, F. J., Sabine, C. L., Dickson, A. G., Goyet, C., Park, G.-H., Wanninkhof, R., Feely, R. A., and Key, R. M.: Global relationships of total alkalinity with salinity and temperature in surface waters of the world's oceans, Geophys. Res. Lett., 33, 1-5, 2006.

Leinweber, A. and Gruber, N.: Variability and trends of ocean acidification in the Southern California Current System: a time series from Santa Monica Bay, J. Geophys. Res. Ocean., 118, 36223633, 2013.

Leinweber, A., Gruber, N., Frenzel, H., Friederich, G. E., and Chavez, F. P.: Diurnal carbon cycling in the surface ocean and lower atmosphere of Santa Monica Bay, California, Geophys. Res. Lett., 36, 3-7, 2009.

Liu, X., Patsavas, M. C., and Byrne, R. H.: Purification and characterization of meta-cresol purple for spectrophotometric seawater pH measurements, Environ. Sci. Technol., 45, 4862-4868, 2011.

Lueker, T. J., Dickson, A. G., and Keeling, C. D.: Ocean $p \mathrm{CO}_{2}$ calculated from dissolved inorganic carbon, alkalinity, and equations for $\mathrm{K}_{1}$ and $\mathrm{K}_{2}$ : validation based on laboratory measurements of $\mathrm{CO}_{2}$ in gas and seawater at equilibrium, Mar. Chem., 70, 105-119, 2000.

Martz, T. R., Connery, J. G., and Johnson, K. S.: Testing the Honeywell Durafet for seawater $\mathrm{pH}$ applications, Limnol. Oceanogr. Methods, 8, 172-184, 2010. 
Martz, T. R., Takeshita, Y., Rolph, R., and Bresnahan, P.: Tracer monitored titrations: measurement of dissolved oxygen., Anal. Chem., 84, 290-296, 2012.

Martz, T. R., Send, U., Ohman, M. D., Takeshita, Y., Bresnahan, P., Kim, H.-J., and Nam, S.: Dynamic variability of biogeochemical ratios in the Southern California Current System, Geophys. Res. Lett., 41, 2496-2501, 2014

Matsumoto, K. and Gruber, N.: How accurate is the estimation of anthropogenic carbon in the ocean? An evaluation of the $\Delta C^{*}$ method, Global Biogeochem. Cy., 19, 1-17, 2005.

McElhany, P. and Busch, D. S.: Appropriate $p \mathrm{CO}_{2}$ treatments in ocean acidification experiments, Mar. Biol., 160, 1807-1812, 2013.

McNeil, B. I. and Matear, R. J.: Southern Ocean acidification: a tipping point at $450 \mathrm{ppm}$ atmospheric $\mathrm{CO}_{2}$, Proc. Natl. Acad. Sci. USA, 105, 18860-18864, 2008.

Mehrbach, C., Culberson, C. H., Hawley, J. E., and Pytkowicz, R. M.: Measurement of the apparent dissociation constants of carbonic acid in seawater at atmospheric pressure, Limnol. Oceanogr., 18, 897-907, 1973.

Nam, S., Kim, H.-J., and Send, U.: Amplification of hypoxic and acidic events by La Niña conditions on the continental shelf off California, Geophys. Res. Lett., 38, 1-5, 2011.

Nam, S., Takeshita, Y., Frieder, C. A., Martz, T., and Ballard, J.: Seasonal advection of Pacific Equatorial Water alters oxygen and $\mathrm{pH}$ in the Southern California Bight, J. Geophys. Res. Ocean., 120, 1-13, doi:10.1002/2015JC010859, 2015.

Navarro, M. O.: Consequences of environmental variability for spawning and embryo development of inshore market squid Doryteuthis opalescens, Ph.D. thesis, Unviersity of California San Diego. Ann Arbor, USA, ProQuest Dissertations and Theses (Publication no. 3644287), 2014.

Navarro, M. O., Parnell, P. E., and Levin, L. A.: Year-round spawning of the Market Squid, Doryteuthis opalescens and associated critical habitat along an upwelling margin, in: Coastal and Estuarine Research Federation National Conference, San Diego, 2013.

O'Sullivan, D. W. and Millero, F. J.: Continual measurement of the total inorganic carbon in surface seawater, Mar. Chem., 60, 7583, 1998.

Padilla-Gamiño, J. L., Kelly, M. W., Evans, T. G., and Hofmann, G. E.: Temperature and $\mathrm{CO}_{2}$ additively regulate physiology, morphology and genomic responses of larval sea urchins, Strongylocentrotus purpuratus, Proc. R. Soc. B Biol. Sci., 280, 20130155, doi:10.1098/rspb.2013.0155, 2013.

Pineda, J.: Predictable upwelling and the shoreward transport of planktonic larvae by internal tidal bores, Science, 253, 548-551, 1991.

Price, N. N., Martz, T. R., Brainard, R. E., and Smith, J. E.: Diel variability in seawater $\mathrm{pH}$ relates to calcification and benthic community structure on coral reefs, PLoS One, 7, e43843, doi:10.1371/journal.pone.0043843, 2012.

Reum, J. C. P., Alin, S. R., Feely, R. A., Newton, J., Warner, M., and McElhany, P.: Seasonal carbonate chemistry covariation with temperature, oxygen, and salinity in a fjord estuary: Implications for the design of ocean acidification experiments, PLoS One, 9, e89619, doi:10.1371/journal.pone.0089619, 2014.
Reum, J. C. P., Alin, S. R., Harvey, C. J., Bednarsek, N., Evans, W., Feely, R. A., Hales, B., Lucey, N., Mathis, J. T., McElhany, P., Newton, J., Newton, J., and Sabine, C. L.: Interpretation and design of ocean acidification experiments in upwelling systems in the context of carbonate chemistry co-variation with temperature and oxygen, ICES J. Mar. Sci., 528-536, 2015.

Rivkin, R. B. and Legendre, L.: Biogenic carbon cycling in the upper ocean: effects of microbial respiration, Science, 291, 23982400, 2001.

Rodolfo-Metalpa, R., Houlbrèque, F., Tambutté, É., Boisson, F., Baggini, C., Patti, F. P., Jeffree, R., Fine, M., Foggo, A., Gattuso, J.-P., and Hall-Spencer, J. M.: Coral and mollusc resistance to ocean acidification adversely affected by warming, Nat. Clim. Change, 1, 308-312, 2011.

Rykaczewski, R. R. and Dunne, J. P.: Enhanced nutrient supply to the California Current Ecosystem with global warming and increased stratification in an earth system model, Geophys. Res. Lett., 37, 1-5, 2010.

Sabine, C. L. and Tanhua, T.: Estimation of anthropogenic $\mathrm{CO}_{2}$ inventories in the ocean, Ann. Rev. Mar. Sci., 2, 175-198, 2010.

Sabine, C. L., Feely, R. A., Key, R. M., Bullister, J. L., Millero, F. J., Lee, K., Peng, T.-H., Tilbrook, B., Ono, T., and Wong, C. S.: Distribution of anthropogenic $\mathrm{CO}_{2}$ in the Pacific Ocean, Global Biogeochem. Cy., 16, 1-17, 2002.

Send, U. and Nam, S.: Relaxation from upwelling: the effect on dissolved oxygen on the continental shelf, J. Geophys. Res., 117 $1-9,2012$.

Smith, T. M., Reynolds, R. W., Peterson, T. C., and Lawrimore, J.: Improvements to NOAA's historical merged land-ocean surface temperature analysis (1880-2006), J. Clim., 21, 2283-2296, 2008.

Somero, G. N.: Thermal physiology and vertical zonation of intertidal animals: optima, limits, and costs of living, Integr. Comp. Biol., 42, 780-789, 2002.

Sunda, W. G. and Cai, W.-J.: Eutrophication induced $\mathrm{CO}_{2}$ acidification of subsurface coastal waters: interactive effects of temperature, salinity, and atmospheric $p \mathrm{CO}_{2}$, Environ. Sci. Technol., 46, 10651-10659, 2012.

Sutton, A. J., Feely, R. A., Sabine, C. L., McPhaden, M. J., Takahashi, T., Chavez, F. P., Friederich, G. E., and Mathis, J. T.: Natural variability and anthropogenic change in equatorial Pacific surface ocean $p \mathrm{CO}_{2}$ and $\mathrm{pH}$, Global Biogeochem. Cy., 28, 1-15, 2014.

Swart, N. C., Allen, S. E., and Greenan, B. J. W.: Resonant amplification of subinertial tides in a submarine canyon, J. Geophys. Res., 116, 1-14, 2011.

Van Heuven, S., Pierrot, D., Rae, J. W. B., Lewis, E., and Wallace, D. W.: MATLAB Program Developed for $\mathrm{CO}_{2}$ System Calculations, ORNL/CDIAC-105b, http://cdiac.ornl.gov/ftp/co2sys/ CO2SYS_calc_MATLAB_v1.1/, 2011.

Waldbusser, G. G., Hales, B., Langdon, C. J., Haley, B. A., Schrader, P., Brunner, E. L., Gray, M. W., Miller, C. A., and Gimenez, I.: Saturation-state sensitivity of marine bivalve larvae to ocean acidification, Nat. Clim. Change, 5, 273-280, 2015. 